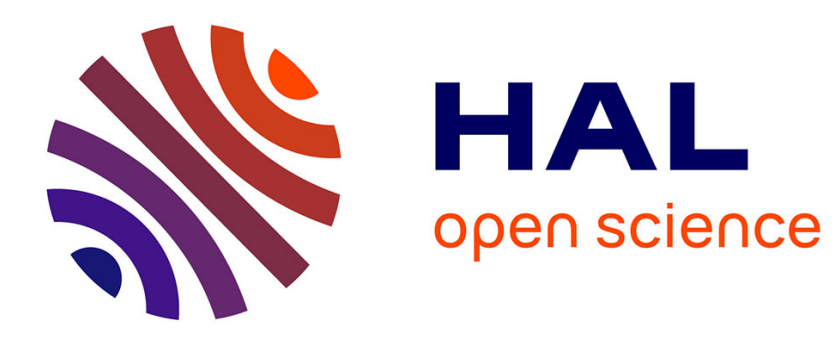

\title{
The changing tides of port geography (1950-2012)
}

Koi Yu Adolf Ng, César Ducruet

\section{To cite this version:}

Koi Yu Adolf Ng, César Ducruet. The changing tides of port geography (1950-2012). Progress in Human Geography, 2014, 38 (6), pp.785-823. 10.1177/0309132513516178 . halshs-01359160

\section{HAL Id: halshs-01359160 https://shs.hal.science/halshs-01359160}

Submitted on 2 Sep 2016

HAL is a multi-disciplinary open access archive for the deposit and dissemination of scientific research documents, whether they are published or not. The documents may come from teaching and research institutions in France or abroad, or from public or private research centers.
L'archive ouverte pluridisciplinaire HAL, est destinée au dépôt et à la diffusion de documents scientifiques de niveau recherche, publiés ou non, émanant des établissements d'enseignement et de recherche français ou étrangers, des laboratoires publics ou privés. 


\title{
THE CHANGING TIDES OF PORT GEOGRAPHY (1950-2012)
}

Pre-final version of the article published in Progress in Human Geography, 38(6): 785-823, 2014

\author{
Adolf K.Y. Ng \\ Department of Supply Chain Management \\ I.H. Asper School of Business \\ University of Manitoba \\ 686-181 Freedman Crescent \\ Winnipeg, Manitoba, Canada, R3T 5V4 \\ Tel: +1-204-474-6594 \\ Fax: +1-204-474-7530 \\ E-mail: adolf.ng@ad.umanitoba.ca
}

\author{
César Ducruet \\ National Centre for Scientific Research (CNRS) \\ UMR 8504 Géographie-cités \\ 13 rue du Four 75006, Paris, France \\ Tel: 0140464007 \\ Fax: 0140464009 \\ E-mail: $\underline{\text { cdu@parisgeo.cnrs.fr }}$
}

\begin{abstract}
Human geographers actively studied ports in past decades. However, the extent to which port geography constituted a specific research stream within human geography remained largely unanswered. By reviewing 399 port papers published in major geography journals, the authors critically investigated the trends and changing tides of port geography research. The findings point out the emergence of the core community shifting from mainstream geography research to increasing connection with other disciplines, notably transport studies. The paper offers a progressive view on human geographers' abilities to form a research community on port development, while identifying opportunities in the pursuit of collaboration between different academic disciplines.
\end{abstract}

Keywords: port geography; bibliometrics; citations; research trends; social network analysis 


\section{INTRODUCTION}

Being the point of interaction between land and sea, ports traditionally served as the economic and cultural centres of cities and surrounding regions. However, the contemporary technological advancement in shipping, increase in international trade and the global division of labor had fundamentally transformed the nature of ports. Notably, the process of 'terminalization' of port operations greatly modified their roles in transport networks and global supply chains, which implied an increased spatial and functional segregation between port, urban and regional activities (Olivier and Slack, 2006; Ng, 2012). In this regard, human geographers were especially active in the description of port's evolution and development, providing numerous theoretical/conceptual models and empirical cases in the past decades. The publication of influential books (for example, Bird, 1963; Hoyle and Hilling, 1984; Hoyle and Pinder, 1992; Pinder and Slack, 2004; Wang et al., 2007; Notteboom et al., 2009; Hall et al., 2011) and scholarly papers (to be further discussed) by transport geographers became increasingly important in defining the evolution and research trends of port geography alongside with other scientific disciplines, say, economics, finance, management science, to name but a few. Indeed, ports, as seen by Shaw and Sidaway (2011), are one of the potential tracks through which transport geography may improve its position within future geography research. In 2012, a special issue, entitled 'The Geography of Maritime Transportation' was featured in Maritime Policy \& Management (volume 39, no. 2), a flagship journal in port and shipping research. This strengthened the proposition that human geographers, as well as geographical theories and concepts, could offer important contributions to port research, and that the experiences from ports could significantly contribute to progress discussions and debates in contemporary issues within human geography ( $\mathrm{Ng}$ and Wilmsmeier, 2012). Several other special issues dedicated to ports were also published in mainstream geography journals, such as Tijdschrift voor Economische en Sociale Geografie (TESG) in 1996, Geojournal in 1986 and 2009, and Environment and Planning $A$ in 2006 about the interrelations between economic and transport geographies, including a number of port articles at centre stage.

Despite such abundance, several challenging research questions have yet to be answered satisfactorily: to what extents do port geographers constitute a specific research body, and how have they adapted to changes in both port development and research? Were they, as claimed by Keeling (2007), stuck in the narrow confines of network structure and flows? While acknowledging the existence of previous reviews on port research, those overwhelmingly focused on the economic, management and performance aspects of ports and did not explicitly identify port geography papers as a distinct research arena (for example: Heaver, 2006; Pallis et al., 2010 and 2011; Suykens and van de Voorde, 1998; Woo et al., 2011) ${ }^{1}$, despite that port geography often (tried to) distinguished itself from port studies within other disciplines (cf. $\mathrm{Ng}$, 2013). Hence, despite the featuring of nearly 400 port papers in major (human) geography journals since the 1950s, until now, there are inadequate systematic investigations on the nature, evolution and research trends of port geography, with $\mathrm{Ng}$ (2013) being the only notable exception to date. However, while he had reviewed the historical evolution of port geography papers since the late 1960s, still, important research gaps have yet to be filled: How did port geographers identify themselves? How was the nature and structure the port geography papers research community? What were the impacts of their works to human geography and other scientific disciplines? To what extent were they receptive to the ideas and contribution from other scientific disciplines, and how was such influence reflected in their research works? 
More importantly, there is an urgent need to answer on whether diversification exists in authorships and citations throughout geography and other scientific disciplines, and whether port geography has a trend of following the latter, especially given the increasing interdisciplinary nature of port research through collaboration between scholars from diversified academic backgrounds (cf. Ng, 2013; Rigg et al., 2012). The extent of the influences and diffusion the research works by port geographers to human geography and other scientific disciplines - their 'social network' within the scholarly community, would be pivotal to provide a comprehensive insight to existing and future port geographers on future research direction.

Understanding such necessity, this paper analyzes the changing tides of port geography through a bibliometric analysis on 399 port geography papers published in major international scholarly geography journals between 1950 and 2012. It provides a general picture on the terrain of port geography papers research highlighting its key characteristics and transformation. Second, it applies Social Network Analysis (SNA) methods to investigate the cohesiveness of the port geography papers community internally and in relation with both human geography and other scientific disciplines, mainly based on citations and coauthorships. This study is a prompt response to the work by $\mathrm{Ng}$ (2013) who calls for further research on citation analysis so as to comprehensively understand the dynamics between port geographers, (non-port) geographers and scientists from other academic disciplines. By doing so, one can understand what have been the scope and influence of port geography research, while highlighting the most central publications and their linkages. It provides human geographers, and other researchers, a clearer view of their abilities to form a research community and to tackle crucial issues on port development, while identifying weaknesses and new opportunities in the pursuit of increased interactions between scholars from different scientific disciplines. The rest of the paper is structured as follows. The study sample, methodology and results will be described and illustrated in sections 2 and 3, respectively, while the analytical discussion and conclusion can finally be found in section 4 .

\section{Study Sample}

To investigate the stated research questions, we reviewed a sample of most of the important peer-reviewed port geography papers published in internationally recognized geography journals. The listed journals in table 1 belonged to those which had featured at least one port geography paper between 1950 and 2012, recognizing that fundamental transformation of contemporary shipping and ports started to take root in the 1950s (cf. Heaver, 2002).

Table 1. Distribution of port geography papers by journal and period, 1950-2012 [Insert Table 1 here]

Together the journals listed in table 1 featured 399 papers (co-)authored by 328 authors in 36 internationally-recognized (human) geography scholarly journals. See Appendix I for the full list of port geography papers included in this study. Also, the list only consisted of papers published in English, while other types of publications, e.g., books, conference papers, book chapters, theses, professional magazines, etc., were excluded. 
Papers were chosen for their central focus on port-related issues while geography journals are those listed in the ISI Web of Science to which we have added GeoJournal, due to its international character. Papers addressing port-related issues in a very secondary manner were excluded, as in the case of some about shipping trends or urban waterfronts where ports themselves were not discussed in detail. Due to the fact that many papers about ports have been published in non-geographical journals, thus making the boundaries of port geography rather fuzzy, an "extended port geography" corpus of 268 papers has been selected on the basis of the following inclusive criteria:

- At least one citation of and/or by a core port geography paper;

- A central interest on port-related issues;

- The recognition of differences across space between locations.

The main difference between core and extended port geography is the importance given to geographical elements in the review process. Yet, some extended port geography papers may in reality more strongly develop spatial and/or geographical issues than some core geography papers giving privilege to other aspects such as policy, governance, and actors. The major journals which have published extended port geography papers in our study period are listed in Appendix II. Here it was not difficult to find that extended port geography papers concentrated in (maritime) transport (e.g., Maritime Policy \& Management, Maritime Economics \& Logistics, Transport Policy, etc.) and urban/regional planning journals (e.g., Cities, Growth and Change, Urban Studies, etc.). Over the entire period under consideration, 107 journals published 279 extended port geography papers, of which 50\% concentrated in ten journals only where Cities and Growth and Change are the only non-transport journals. All disciplines are represented, from history to planning, business management, and even anthropology.

To facilitate our analysis, the study period has been divided either by decades or into four 'sub-periods' (1950-1974; 1975-1990; 1991-2001 and 2002-2012). Generally speaking, the former and latter two periods can be understood as the 'classical' and 'contemporary' ages in port geography papers research, respectively ( $\mathrm{Ng}, 2013)$. Such a division was supported by Pallis et al. (2010) who indicated that the early 1990s served as a watershed where research interests in the port sector (both geography and non-geography) had grown substantially. The approach applied to our sample rests on collaboration (co-authorship) and citation analysis within and between papers. Collaborations are analyzed on the basis of authors having written together some of the articles, which allows for measuring the rate of single-authored papers and representing the network of co-authors at different periods in order to verify its underlying community structure. Although there are different reasons on why a paper should be cited, citations provide useful data to measure and map the evolution of inbound and outbound influences of a given corpus (Newman, 2010).

\section{Results}

\section{Production of Port Geography Papers}


Figure 1 illustrated the trend of port geography papers published in major geography and other journals between 1950 and 2012. Following a period of prominent activity in the 1950s and 1960 s, there is a noticeable drop in the number of core port geography papers from the 1970s, while the production level goes back to the one of the 1960s only in the 2010s. This trend occurs in parallel with a regular growth of extended port geography papers, thereby making the total reaching unprecedented volumes in the last decade. Papers published outside geography journals have increased their share from about $4 \%$ in the 1950 s to $58 \%$ in the 2010 s, thereby becoming dominant in the total. In fact, core port geography has remained somewhat stable along the period in comparison with extended port geography. This underlines a very important shift with a moving away of port geographers towards more specialized journals and a lesser interest for geographical thought from other port specialists.

Figure 1. Production trend: core port geography vs. extended port geography papers, 19502012

[Insert Figure 1 here]

Certain geography journals published port geography papers only during the early years (before 1990). Among them, AAG had 31 such papers between 1950 and 1979, while GEG had 33 between 1950 and 1989. On the contrary, some geography journals featured more port geography papers recently, say, EPA, EPS, GEF, GEJ, to name but a few. For example, since 1980, EPA and GEJ had featured 12 and 23 such papers, respectively. At the same time and despite a certain decline, there was also a rather stable distribution of port geography papers in particular geography journals, such as TEG, GRV and ECG. For example, a roughly even distribution of port geography papers could be found in TESG between 1950 and 2012. Until the time when this study took place, it had 73 papers on port geography research. ECG and GRV have 22 and 17 papers respectively throughout the indicated period. Also, it was interesting to note that JTG possessed the largest number of port geography papers. Though only being established in 1993 (very recently when compared to many other geography journals), it featured 60 port geography papers since its establishment, and had become a very important geography outlet for port geography papers in the past two decades. The rest appears to have had a relatively minor role in port geography papers production, except for EPA (of which a special issue was published in 2006), PRG (until the 1990s), and CAG. This suggests a retreat of port geography papers from major general geography journals that cover a wide diversity of issues and focus on innovative research, and a concentration upon secondtier or more specialized journals keeping a demand for more classical topics such as ports. As seen from Table 1, geography journals were more advanced in the production about ports but they have become quantitatively secondary compared with the total of other journals since the 1980s. JTG is largely responsible for the maintained production of core port geography and its slight 'recovery' during the 2010 s, without which this field would have simply disappeared from geography journals, as it concentrated 23, 28, and 69 percent of all core port geography production since the 1990s. Such trends may be explained by three main and complementary factors:

- Geographers once interested in ports have shifted their interest towards other topics more in accordance with mainstream geography, notably with the decline of the quantitative turn during the 1980s affecting transport geography in general (Waters, 2006), and the increasing preference for other transport modes such as railway and airlines, people mobility, communication and more 'virtual', rather than freight, flows 
(Hall and Hesse, 2012). Some renowned scholars are identified in the core port geography corpus in the early period, such as a paper by the French geographer Jean Gottmann (1961) on the port of Baltimore, published the same year than his seminal work where the concept of megalopolis was first proposed based on the case of the United States' northeastern seaboard urban concentration;

- Geographers interested in ports have strengthened the applied dimension of their works by publishing in other journals such as transport journals, with a tendency to address spatial and territorial issues in a secondary manner compared with economic and management issues, while promoting spatial and territorial issues towards other nongeographic fields. This trend occurred in parallel of the former whereby most of the geographers once interested in ports shifted their focus toward wider urban and mobility issues, while others such as James Bird led a radical "crusade" against the ignorance of port activities and functions by urban spatial models such as the central place theory, and proposed general books where the port received foremost attention alongside other locally grounded activities (see Bird, 1977);

- Perhaps, this also implies that port geographers have found it increasingly difficult to innovate in human geography itself while getting closer to their specific industry of interests. In relation with the former factors, the growing specialization of port specialists and the growing distance from general discussions on mobility, flows, space, and scale for instance, accelerated their retreat from geography journals that in the meantime had to strengthen their audience, with a growing importance of impact factors and innovative approaches.

Alongside such trends, there also has been an evolution of the geographic coverage of the corpus both in terms of affiliations and study focus (Figure 2). One major tendency is the decrease and increase of African and Asian research, respectively, while Europe has gained grounds compared with the Americas and Oceania. Europe constitutes about $70 \%$ of affiliations and $50 \%$ of research foci in the early 2010s. This situation is the inverse of the one in the 1950s with the notable exception that American ports have never attracted as much attention as European ports. Europe has indeed been a fertile ground for studies of port competition but also supply chain management in relation to ports, as well as urban waterfront redevelopments. Another explanation is the wider context of those studies: de-colonization is largely responsible for the decline of port-related African studies, while many theories and models used by geographers originate from African regions, such as the ideal-typical sequence model of corridor development by Taaffe et al. (1963). The growing interest for Asia mainly comes from the close connection of export-oriented and free zone policies with port development across the region that also comprises many of the world's major ports such as Hong Kong and Singapore, but also Korea and China. Such trends indicate that the evolution of port geography well illustrates the evolution of the world economy and of human geography as a whole, notwithstanding certain gaps to be further addressed in the following sections.

Figure 2. Geographic coverage of port geography papers, 1950-2012

[Insert Figure 2 here] 


\section{Collaborations: The Emergence of a Community?}

As suggested by Newman (2004), the mean number of authors per paper, as well as the percentage of single author papers, is an interesting indicator to look at when considering a given scientific corpus and its collaboration dynamics. In the case of port geography papers (Table 2), there has been a continuous increase in the total and average number of authors since the 1950s as well as a constant decrease in the share of single-authored papers. However, still in the 1980s, 66 percent of all port geography papers were single-authored, half in the 1990s, before a sudden drop in the 2000s (31\%) and in the 2010s to 6 percent. Such trends are comparable amongst core and extended port geography, with a slightly more collaborative profile for extended port geography due to its higher average number of authors, but core port geography keeps a lower share of singe-authored papers than the latter along the period.

Table 2: Bibliometric indicators on port geography papers, 1950-2012

[Insert Table 2 here]

Mapping the collaborations (Figure 3) among authors at distinct periods confirms the fragmentation of research during the first phases (1950-1974, 1975-1990) where collaborations are in minority, followed by the emergence of larger - albeit still small and isolated - subgroups in the period 1991-2001, and of a giant component connecting the majority of researchers in the last period 2002-2012. In the latter period, 45 of the 102 authors are connected directly or indirectly thus forming a community. The rest of the authors form separated cliques (or isolates), as they have never formally collaborated with the central community.

An interesting trend is that the largest - albeit very small - component in 1991-2001 rests on some authors being well represented in the second period (i.e., Slack, Rodrigue and Comtois). This Canadian clique forms in the second period a larger ensemble connected directly with Asian and French colleagues. Calculating the 'betweenness' centrality of authors in the network (grayscale) confirms the strong correlation with the number of collaborations (size) as well as to identify the main brokers (Newman, 2004). While Slack, Ducruet and Notteboom are the most collaborative, the overall structure is strongly dependent upon the 'brokering' role of Frémont between those three subgroups. The latter author has notably pioneered a biannual meeting of port geographers welcoming most of the connected researchers (Le Havre 2003, Hong Kong 2005, Antwerp and Rotterdam 2007, and Montreal 2009). This large community is largely French speaking, though it collaborates mostly in English and the three aforementioned main poles broadly correspond to France-Canada-Asia (Slack and Frémont), Belgium-Netherlands (Notteboom), and Europe-Asia (Ducruet). The extent to which this community will be maintained, further integrated or disintegrated will depend on upcoming publications in the field as well as on further collaborative efforts. At present, the relatively strong density of the core community as reflected by an average clustering coefficient of 0.64 is in fact dependent upon a few large nodes having distinct subgroups and limited transversal linkages.

Figure 3. Graph illustrating port geography research co-authorships, 1950-2012

[Insert Figure 2 here] 


\section{Port Geography Papers Citing: Background and Imports}

The counting and classification of citations by port geography papers works by decade clearly underlines a trend of background diversification (Figure 4). A first period is characterized by a dominance of geographical inspiration, but from the 1970s onwards, the share of geography journals (of which core port geography papers) is constantly dropping, from $85 \%$ of all citations in the 1950s and 1960s to about 35\% in the 2010s. Transport journals have become dominant in the last period, from $8 \%$ in the 1960 s to $28 \%$ in the 2010 s. Although citations to core port geography papers have dropped from $43 \%$ in the 1950 s to $22 \%$ in the current decade, the combined share of core and extended port geography remains somewhat stable along the period, from $48 \%$ in the 1950 s to $39 \%$ in the 2010s. On the one hand, port geographers shifted their knowledge sources towards more specialized works in various fields (e.g., economics, business, management, transport and logistics), but on the other hand, they have valued port geography papers itself and the spatial approach to ports outside their original nest (geographical journals). It may have become necessary for port geographers to confront their own views with the ones of transport specialists while adopting concepts and methods from other mainstream research arenas. Such results are largely influenced by the aforementioned shift of port geographers towards transport journals.

Figure 4. Distribution of journal papers under different disciplines cited by core port geography papers, 1950-2012

[Insert Figure 4 here]

Another way to better understand the changing scope and nature of port geography papers is to build a database of papers cited by port geographers. Choosing papers as the unit of analysis rather than authors (or journals) avoids the problems of multiple authors. The resulting directed graph of citations based on port geography papers citing other papers contains 2,698 papers and 4,507 links among them when the whole period (1950-2012) is considered. However in the graph, citations between core port geography papers were removed so as to better understand the connecting role of other papers between them. This operation is also useful to make the graphs more readable, to lower the probability of self-citations in the corpus that would inflate papers' centralities, and to test whether the citations graph remains connected and how despite the removal of internal links. Papers are differentiated by a different color according to their main research areas as in the previous figures, and the size of nodes represents the betweenness centrality of the papers, i.e. their overall accessibility as measured by the number of occurrences on possible shortest paths across the entire network. This indicator has been preferred to in-degree (number of times a paper is cited) in order to better identify bridge positions: it better expresses whether a paper is pivotal in the circulation of knowledge within the entire corpus, regardless of its volume of citations, as the top papers are usually known by scholars in the field. However, betweenness centrality may be artificially inflated in the case of papers being at the edge of the network while being the only 
access to it for a few other papers. A Gem-Frick visualization algorithm (TULIP software) is applied to represent the results with most central papers in the middle of figures and less connected papers at its periphery, while topological proximity in the graph might in fact illustrate other proximities such as geographical and/or disciplinary. This analysis is useful to detect key papers and to verify the role of disciplinary belonging in network formation and knowledge diffusion: how is port geography papers dependent from other scientific disciplines as well as from their own, and how homogenous is its scientific background?

The four stated periods are compared in Figure 5. In the first period (1955-1974), most connected papers forming two important subgroups belong to core port geography and constitute the backbone of the network, among which the two seminal essays of Weigend (1956, 1958) on port geography and the spatial model of port evolution provided by Rimmer (1967) with an application to Australia as well as his work on port classification (1966). The fact that the largest component is centered upon a geography paper, the ideal-typical phased model of corridor development by Taaffe et al. (1963), is emblematic of this "classic" period during which port studies were well integrated with wier geographical approaches. . The rest of the network, however, which still concentrates the majority of works, remains rather dispersed. A distinct community appears, however, with the works of Hanse and Van Dongen (1956, 1958) on African ports. The works of Mayer (1955) on Chicago, Bird (1965) on Australia and on theoretical aspects (1970), Hilling (1969) and Ogundana (1972) on Africa also tend to have developed in relative autarchy. There seems to be a strong regional specialization among port geographers in complement to a number of general approaches, reflecting upon Figure 2 with a high share of research on Africa during this period. Even same authors' papers remain disconnected, such as Hoyle's work on African ports (1967, 1968). Other isolates are better explained by their original approach outside the "mainstream", such as the work on images of colonial Port Royal by Kovacik and Rowland (1973) and the one of Fordham (1970) on port-airport interactions. Interestingly, there is a tendency for isolated papers to focus more on non-geographical sources rather than port geography itself.

The second period (1975-1990) provides a similar network pattern with a core community centered upon port geography papers and some isolates or peripheral papers with a more diversified background. The model of Taaffe et al. (1963) remains central to port geography papers for the aforementioned reasons. Most central papers are still general surveys and discussions, such as the one of Bird (1980) on gateways, Hayuth (1981) on load centers, Hilling (1983) on developing countries, Hoyle (1989) on the port-city interface, but also Slack (1980) on technological changes in sea transportation. Future evolutions of port geography papers seem to have given privilege to the second influence, namely the economic dimension rather than spatial analysis. Some papers remain rather central although they barely connect with other port geographical works, such as Hoare (1986) on British ports, Miklius and Wu (1988) on forecasts, while some other papers are not connected at all. The latter are, again, characterized by case studies on developing countries such as Hoyle (1978, 1986), Omiunu 
(1989), and Stanley (1990) on African ports, as well as McCalla (1990) on free zones. Another characteristic of isolates is their dominant economic focus, such as Slack (1989) on the port service industry, but also Wallace (1975) on Canadian ports, Kinsey (1981) and Stevens et al. (1981) on impact multipliers and economic effects of port activities, West (1989) on economic rents, and Suykens (1989) on port-city economic relationships, while others are more characterized by historical approaches (Pred, 1984) and recreational issues (Sant, 1990). Most case studies still remain very much Western-focused, such as Slack (1990) on US inland load centers, Hayuth (1988) on the US container port system, O'Connor (1989) on Australia, with the exception of Marti (1985) on Chilean ports.

The third period (1991-2001) is defined by a significant reduction in the number of isolates and by an overall diversification of papers' background (Figure 4). One dominant community contains the majority of papers. One drastic change is the highest centrality of case studies on ports outside Western countries, such as East Africa (Hoyle and Charlier, 1995), Hong Kong (Wang, 1998; Airriess, 2001), and Singapore (Airriess, 2001), but also China outside the largest component (Todd, 1993, 1997). Other core papers continue to develop classical issues such as on urban waterfronts (Norcliffe et al., 1996; Hoyle, 2000) with a central focus on Western ports such as Notteboom (1997) and Charlier (1996) on the European and Benelux port systems, respectively. General papers are not the most central but keep important positions as seen with the discussion by Van Klink and Van den Berg (1998) on gateways and intermodalism, Van Klink (1998) on port networks, and Cullinane and Khana (2000) on the geographical implications of growing vessel sizes. As in the previous periods, 'peripheral' papers are those having a distinct focus such as geo-historical (Waitt and Hartig, 1997; Herod, 1997, 1998; Groote et al., 1999; Castree, 2000), cultural (Stevenson, 1996), or discussing specific issues such as clusters and spillovers (Oosterhaven et al., 2001) without sharing same references with other port geography papers. Important papers outside the port geography paper category are in fact the work of port geographers, such as Charlier and Ridolfi (1994) on intermodalism. Friedmann (1986) on the world city hypothesis is one of the rare nongeographical works to stand out but it remains at the periphery.

Finally, the fourth period (2002-2011) is marked by a high network complexity due to the large number of papers being considered and their intricate relations. The main trend is the highest centrality of papers offering a synthesis to port geography papers; they innovate by either providing new concepts, such as Olivier and Slack (2006) on the 'terminalization' of ports, Lee et al. (2008) on global hub port cities, Lee and Ducruet (2009) on spatial glocalization, Notteboom (2010) on multi-port gateway regions, , Ng and Pallis (2010) on institutions and port governance, Jacobs and Notteboom (2011) on evolutionary perspectives, or through large-scale empirical applications of classical methods such as Ducruet and Notteboom (2012) visualizing and measuring the worldwide maritime network of container shipping. Papers standing out while being well-connected with the core are thus those making links with other fields outside port geography papers, other examples being Fowler (2006) on 
networks, $\mathrm{Ng}$ and Tongzon (2011) on dry ports and regional development, O'Connor (2010) on global city regions and logistics, Franc and Van der Horst (2010) on hinterland service integration, and Wang and Ducruet (2012) on the emergence of the Shanghai-Yangshan multilayered gateway hub. One major difference with former period is the highest centrality score attributed to an extended port geography paper about port regionalization (Notteboom and Rodrigue, 2005). Transport papers have gained enormous important in the network compared with previous periods, such as Robinson (2002) on ports in value-driven chain systems, Slack et al. (2002) on strategic alliances, and Notteboom and Winkelmans (2001) on structural changes in logistics. Most peripheral port geography papers are in fact much closer to urban-related issues as they principally focus on waterfronts (for example, Oakley, 2009) or on specific issues such as remote sensing (Kaiser, 2009). The graph is in fact organized by regions, with waterfront and social issues on the left having more connections with geographical issues and less with the transport field, and transport issues on the right being less connected with geography and other fields. By no means port geography has evolved from a scattered community to a more tightly connected one in terms of shared ideas and concepts, but the reference to geography has shifted to the periphery while transport studies have become more central in the graph.

Figure 5. Graph illustrating citations by port geography papers, 1950-2012 [Insert Figure 5 here]

\section{Port Geography Papers Cited: Diffusion and Exports}

The distribution of papers citing port geography papers exhibits a very similar trend with the previous analysis, with an increasing share of transport and other journals compared with geography and port geography papers (Figure 6). Yet, the proportion of transport journals has reached only $13.5 \%$, and geographical journals (of which core port geography papers) are still occupying a $41 \%$ share in the 2010 s. There is clearly a significant imbalance between citing and being cited by others, and this suggests that port geography has widened its scope (previous analysis) in greater ways than its influence towards other disciplines. Another difference with the previous analysis is the growing interests for port geography papers by geographical research until the late 1970s, which decreases gradually since the 1980s. This can be attributed to the behavioral turn in geography having increasingly disregarded transportation issues due to their close affinity with spatial analysis (Waters, 2006). Except from the 1970s, port geography as a whole (core and extended) oscillated around 45-50\% of all citations, which is far above the 34-39\% level for the previous analysis. This imbalance between imports and exports remains a weakness of port geography since it is more cited by itself than by other fields.

Figure 6. Distribution of papers under different disciplines citing port geography papers, 19502012

[Insert Figure 6 here] 
The network analysis of papers citing port geography papers is applied in the same way than the previous analysis. It excludes, however, citations from port geography papers because this would provide similar results. Each port geography paper has been retrieved via Scopus and Google Scholar, and all citations to those papers were compiled while keeping only the peerreviewed journals. As a complement to the previous analysis in the last sub-section, it aims to reveal which papers have attracted most attention from other disciplines at different periods as well as the existence of one or several communities with shared issues and backgrounds (Figure 7). Periods are identical to the previous analysis and they are based on the publication year of citing papers.

Figure 7. Graph illustrating citations of port geography papers, 1950-2012 [Insert Figure 7 here]

During the first period (1955-1974), the network of citations remains rather small and fragmented, containing mostly geographical journals (of which port geography papers). The group of connected papers is a chain-like structure thus having few transversal linkages. The most central paper by Smith (1970) concerns commodity flow analysis and it quotes a bunch of port geography papers about hinterland and foreland traffics having in common methodological issues. Isolates are characterized by groups of papers focusing on a specific terrain, such as New Zealand (Rimmer, 1967), Australia (Solomon, 1963), and Sierra Leone (Jarrett, 1955). This period thus shares a similar structure with the one of citing papers: a core composed of theoretical/methodological papers and isolates specialized on specific areas of the world (developing countries).

Another similarity with the previous analysis is the emergence of a larger core community during the second period (1975-1990). Most central papers outside port geography papers are, in fact, published by port geographers (Airriess, 1989; Marti and Krausse, 1983), focusing on modeling, while Airriess (1989) and Robinson and Chu (1978) connect principally papers on Asian and African ports outside port geography papers. The seminal works of Weigend (1958) on theoretical aspects and Hayuth (1981) on load centers have a pivotal position. Specialization also appears around the works of Hoare (1988) on British ports and on ports' forelands and external relations (Von Schirach-Szmigiel, 1973; Britton, 1965). At this period, port geography papers had thus been attractive due to their special focus on developing countries and their provision of concepts and methods. Isolates are, in general, original contributions on historical geography (Pred, 1984), on gateways (Bird, 1983), on economic impacts (Stevens et al., 1981), on European ports (Bird, 1967) or the work of Rimmer (1967) drawing attention on other issues than ports.

Despite the growth in citations and papers, the third period (1992-2001) consists of a less integrated network. Most central papers are connected by very few links, which denotes a dispersion of research interests due to the lack of central themes: globalization and transport in Africa (Pedersen, 2001), waterfronts (Hoyle, 2000), trading flows (Hoare, 1993), notwithstanding the stability (Hayuth, 1981) and emergence (Fleming and Hayuth, 1994) of theoretical discussions on transport hubs with strong focus on ports, as well as a noticeable shift towards behavioral aspects of port selection and port strategies (Slack, 1990). Among the isolates, the work of Weaver (1998) about the historical geography of trade competition and 
route development quotes port geography papers on Africa, while the one of Hoyle (1999) and Stevens et al. (1981) have their respective subgroups focused on waterfront redevelopment, economic impacts, cultural aspects, and port-city economic relations. This period is a transition phase focusing from case studies, theoretical and methodological works to policy issues.

The fourth period (2002-2012) provides a very complex network of citations structured by a large connected component and few isolates. While most of core papers are from port geography papers, a good number of them are from transport journals and locate near the center; geographical papers remain more central in the graph than in the previous analysis of outward citations, while "other" papers locate more at the fringe of the figure thereby suggesting the existence of specialized communities. Yet, transport journals had a central role in forging this scientific community rather than other journals. Among the most central port geography papers, there is a wide diversity of approaches, with a mix of classic, theoretical works (Olivier and Slack, 2006; Hayuth, 1981), general discussions on transport hubs and gateways (Fleming and Hayuth, 1994; Van Klink and Van den Berg, 1998), waterfronts (Hoyle, 2000), but also empirical studies of global networks (Frémont, 2007). Strong connections with geography journals are the result of transport geographers mostly (Wilmsmeier et al., 2011; Ducruet et al., 2011) notably through general discussions on the trends affecting transport geography itself (Keeling, 2009). Unsurprisingly, the strong position of some transport papers is generally explained by the fact that most are published by port geographers as well through papers focusing on ports, which confirms the shift of port geography papers towards transport journals. The absence of port geographers from nongeographical journals also reinforces the idea according to which transport journals have been privileged by port geographers, and perhaps more accessible and opened to their views than other journals, e.g., business, management, economics, planning, history, natural sciences, operational research, etc.

Hence, there are significant disparities between the first (1950-1990) and final (1991-2012) two periods In the first two periods, port geography research was still largely knitted by generally accepted (port) geography theories and models, and applied to different parts around the world. Complementing Ng's (2013) argument, port geography research during this period closely followed the focus and approach of mainstream human geography, largely being geographers who focused on port-related problems. However, in the third period, a transitory process took place where old theoretical models started to become obsolete while port geography papers research began to move away from geography to transportation and other scientific disciplines. Yet, the ratio between the respective numbers of inward and outward citations has remained highly unbalanced: port geography always imports more than it exports. This suggests a follower rather than a proactive, or even innovative, profile of port geography, notably towards transport and other non-geographical journals. Over the whole period, transport papers have the widest discrepancy between inward and outward citations both in terms of number $(0.48)$ and share $(0.67)$, followed by other studies $(0.50$ and 0.71$)$, geography (0.73 and 1.03), core port geography (0.90 and 1.26), and extended port geography (1.03 and 1.44). Thus, the affinity for transport is largely imbalanced, as this field does not seem to compensate port geographers for their repeated efforts to make their work more practical and applied. Core port geography is thus the biggest importer of core port geography, and this is partly explained by the migration of same scholars to non-geography journals citing their 
works published in geography journals. Yet, such measurements do not include citations of extended port geography papers by transport (and other) journals. It is thus logical that the gradual shift of port geographers towards non-geographical journals had the effect of the effect of lowering the influence of geography journals towards other fields when it comes to port-related research. Given that the most influential port geography papers were published in geography journals, such results remain valid in pointing at a certain weakness of this corpus towards non-geographers. In some way, core port geography remains closer to geography because geographers that do not publish about ports still recognize port geography (almost) as much as port geography recognizes them.

Analyzing the changing share of port-related citations in the total of all citations made by geography and other papers was impossible due to obvious constraints of data collection and availability over the whole academic spectrum. However, such a trend also denotes the ability and necessity to borrow concepts and methods from a vast panel of research fields due to the inherent trans-disciplinary nature of port research. Another positive dimension to be underlined is the regularly growing ratio between the respective cited and citing shares of other journals, from 0.21 in the 1960 s to 1.04 in the 2010s, which could suggest a growing recognition of core port geography towards other social and natural sciences outside the transport field. One example is the study by Frémont (2007) of the port network of Maersk, the world's largest shipping line, being cited by a physics paper (Hu and Zhu, 2009). This is part of a wider trend by which natural sciences increasingly took over classical research fields of social sciences, such as transport network analysis, due to stronger computational power and modeling techniques, but often without quoting the original works done, among others, by geographers (Ducruet and Beauguitte, forthcoming). In the total citations network comprising all inward and outward citations over the entire study period (Appendix III), most central papers are compared by their betweenness centrality and in-degree centrality, while each table includes (III.1) or excludes (III.2) citations between core port geography papers themselves. In the first table, the work by Olivier and Slack (2006) ranks first, as it addresses profound changes in the meaning of the concept of the port itself following the reorganization of terminal operations by global players. It is followed by papers offering large syntheses as well, such as Lee et al. (2008) adding an Asian variation to the mostly Western-focused models of ports' spatial evolution, and $\mathrm{Ng}$ and Pallis (2010) discussing the impacts of institutions on port reform and governance. Unsurprisingly, only few papers in this top 30 come from outside core or extended port geography, such as Sager (2011) on neo-liberal planning policies, Turnbull (2006) on the power relations within the port industry, and Notteboom and Rodrigue (2005) about the regionalization of ports. The second table offers a relatively identical list of papers despite some changes in their ranking, with Taaffe et al. (1963)'s classic model ranking first and Notteboom and Rodrigue (2005) ranking third. Both papers mainly focus about the concept of 'port system', which still nowadays continues to occupy a very central focus in port geography (Wang and Ducruet, 2013), but in a relative isolation from similar concepts such as cities systems or systems of cities developed in urban geography (see for instance Bretagnolle et al., 2009). Papers outside core or extended port geography differing from the previous list are those of Notteboom and Winkelmans (2001) and Robinson (2002) on strategic changes in logistics and value chains. Although the position of papers in such a graph can be anachronical due to the intermingling of periods, it confirms how port geography, as a whole, remains fragmented between social, planning, economic and transport issues, as well as somewhat selfsufficient due to the rarity of centrally located papers from outside this specific research field. 


\section{Discussion and Conclusion}

Despite the rapid transformation of the maritime industries posing significant implications on the roles and functions of ports, there is a scarcity of analysis on the research trend of port geography papers. Recognizing such deficiencies, through a bibliometric analysis on 399 port papers featured in 36 journals (co-)authored by 328 researchers between 1950 and 2012, this paper investigated the evolution and research trends of port geography papers.

A number of observations can be identified. First, there has been an increasing production of port geography papers in recent decades after a period of relative slowdown, which demonstrates that port geography is not a fading research field. On the contrary, it has managed expanding, reaching new frontiers and diversifying its horizons, notwithstanding certain weaknesses. In fact, core port geography has increased not as fast as extended port geography, the latter being published outside geography journals. Second, the analysis of citations concludes to the coexistence of three 'systems' within port geography papers: a 'traditional' system composed of core papers addressing classical issues of transport flows and networks but without strong recognition from outside, a "specialized" system with high recognition from outside but weak linkage with the traditional system and transportation, and finally, an "innovative" system more concerned by societal and methodological issues connecting other social sciences and having wider external impacts. Such imbalance between inward and outward citations suggests a recurrent weakness of port geography that is to import to more than it does export from other research fields and disciplines. Yet, other methods such as co-citations could be applied to refine the analysis of imports and exports, where two or more papers are linked in the network when they cite same papers (Newman, 2004). This is subject to further research. Nevertheless, our results point at the difficulty for port geography to attract non-port specialists, which results in a certain lock-in among port geographers.

This lock-in is about to change given the recent publication of many papers connecting wider theoretical fields (e.g. governance, networks, globalization) that may attract further attention from outside. The shift from port as a place to the port in networks of all kinds (firms, flows) has been identified as a crucial meeting point with wider concerns in economic geography and transport studies, also backed by the renewal of network analysis conceptually and methodologically since the late 1990s (Ducruet and Lugo, 2013). However, port geographers increasingly struggled to re-identify a core research direction. Although attempts were made to fill in this gap (for example, Fleming and Hayuth, 1994), the migration of port geographers to other disciplines had weakened the self 'bonding'. This process was completed during the fourth period where the 'bonding' between port geographers seemed to be even more remote, especially given with increasing collaboration between geography and non-geography scholars. As noted by $\mathrm{Ng}$ (2013), there was a lack of general consensus (yet) on the appropriate theoretical replacements for port geography papers research in view of this migration process, especially within human geography. Hence, port geography is in danger of being relegated to a normal science (cf. Kuhn, 1962) rather than innovative contribution to paradigm shifts. Moreover, there was a worrying indication that the increasing popularity of the so-called 'innovative system' also led the gradual decline of certain traditional areas, notably the interdynamics between port, development and well-beings of its surrounding regions with the core 
geography journals. Indeed, it was shocking to found that there were increasing number of port-city relationship and port-regional development papers - traditionally important topics within human and transport geographies - being published in non-geography journals, with a significant decline in the number port-regional development papers being published in geography ones. Instead, geography journals are now increasingly dominated by 'innovative' topics (a trend similar to non-geography journals), notably port choice and competition, port, intermodal transportation and supply chain, as well as port management, policy and governance (Table 3) ${ }^{2}$.

Table 3. The research themes of port geography papers published in geography and nongeography journals before and after 1990

[Insert Table 3 about here]

The change in research theme is a reflection of the redefinition of what (in human geography terms) 'the relations of and across space and place' mean among port geographers nowadays, i.e., from the relationship and interaction between human activities (port) and the (built) environment to the more 'industrial' meaning between port and other transport modes, production process and inter-port relationship. From a spatial perspective, port geography research had further highlighted the gradually segregated relationship between ports and their surrounding areas (and spatial planning), being replaced by a more practical (at least from the industrial point of view), profit and efficiency-oriented meaning, like 'trade corridors', 'supply chains' and 'competitiveness', of which the approach and methodologies also tended to be more positivist and quantitative, respectively.

However, perhaps this should not be deemed as surprising. Technological revolution, notably the use of containers, and the persistent increase in international trade and globalization, had transformed port evolution and development, like the increasing intensity of inter-port competition. It is well documented that, especially since the 1980s, shipping lines often pressurized ports to enhance efficiency (Hayuth and Hilling, 1992; McCalla, 1999). Slack (2004) argued that such fundamental changes had led to the growing similarity between shipping lines, leading to the phenomenon that while winners won more, losers would lose even more. As a result, ports were forced to find ways to sustain and enhance their competitiveness (Meersman and van de Voorde, 1998), notably through enhancing their performance, service quality, and network position (Ducruet, 2013), as well as identifying major port choice factors (Ng, 2006; Sanchez et al., 2011). Strengthened by the strong wave of neoliberalism in pushing economic policy and development during the same period (Harvey 2005), ports needed to be 'responsive' to customer requirements, thus pushing them to focus on efficiency enhancement (within port itself and between ports and other transport modes), devolution, public-private partnership of port (or terminal) ownership and operations (Heaver, 2002; Wang et al., 2004; $\mathrm{Ng}$ and Pallis, 2010), and the search for quick results (thus overemphasis on quantitative, easily-measurable indicators). The above had transformed port's role and functions so much which posed significant challenges to port researchers, including geographers, to conceptualize and interpret them (Wang et al., 2007).

In addition, analysis from this study further strengthened the proposition that the 'geographical' identity of port geography papers had been significantly diluted in the past 
decades (cf. Ng, 2013). The morphology from core geographical research towards transportation due to an increased specialization of port geography papers on transport issues, however, does not necessarily contradict the emergence of a new phase with more diversified goals and perhaps, more fundamental ones. Indeed, port geography research had evolved from an encyclopedic, secondary nature of geography researchers to become more specialized and primary research interests. The emergence of a connected community in the last decade or so could have been one positive factor for port geographers to exchange ideas faster than in former period of isolation and fragmented collaborations. Indeed, the formation of a single and well-connected community clearly paves the way towards further innovation in the field, although the future of this community will depend on maintained scientific interactions and the development of more transversal linkages among port geographers. New ways of linking port/transport issues with wider theoretical and methodological backgrounds will both profit the port industry and mainstream scholarly research.

Hence, further research is urgently required to comprehensively understand the extent of which port geography papers interact with other scientific disciplines, and to search for the aforementioned new ways. Important topics include the analysis of knowledge interactions between locations through the port geography papers corpus - are port geography papers offering a different pattern than other sciences? Also, further analysis of citations and cocitations based on the categorization of port geography research would allow to verify whether papers discussing similar topics have formed distinct communities, and the "bridges" between them, in relation with the homophile concept in social networks. Internal trends may reflect the evolution of certain 'schools', such as the French one more focused on maritime forelands and the Dutch one better discussing hinterland distribution, towards more global and transversal approaches, but such a study shall integrate domestic journals (of which in other languages) and book publications. Clustering methods could also be applied to verify the influence of geographic or other proximity among authors in the pattern of collaborations and citations, as well as other graph-theoretical approaches such as bipartite (or 2-mode) networks and multilevel networks where author, paper, and journal levels are considered. Finally, there is an equally important need to investigate whether port geography papers research has increasingly focused on the major ports along the major international trade axis, rather than secondary or regional ones. This will help to verify the proposition on whether international trade and globalization has 'bent' the focus and efforts of port geographers towards the 'cores' while missing out the 'peripheries'.

Despite its relatively small field, our analysis has clearly advanced the debate of the role of transport geography in the human geography discipline. The analysis partly confirms the applicability of the rather "ghettoized" dimension of transport geography (cf. Goetz et al., 2003; Keeling, 2007) in general to port geography papers given the somewhat limited impact of its core papers externally and its growing specialization within transport research moving away from mainstream geographical research, except for the top cited papers that have actually limited connections with classical port geography papers. Yet, this study has identified a recent production of more innovative papers connecting both classical port geography papers and wider research fields, backed by the emergence of a connected community of port specialists. Thanks to such collaborations and investigations, port geographers have added a spatial dimension, and an appreciation of institutions and place, to port and other aspects of maritime studies, that otherwise would be a field entirely dominated 
by operational research and business approaches. While port geography still evolves in a relative autonomy that creates disconnection with wider approaches in economic geography for instance, it has been able to integrate important conceptual and methodological shifts such as globalization and networks. Further research is therefore needed to better evaluate the gaps between human and port geographies from a more contents perspective. To sum up, this paper offers invaluable insight on the trends and evolution of port geography research, helping researchers in preparing future research agendas in searching for their new identity as a valuable sub-theme within the human geography, transport and other academic disciplines.

\section{Acknowledgments}

This study is partly funded by the University of Manitoba VPRI and the I.H. Asper School of Business Research Funds (314942). The research leading to these results has received funding from the European Research Council under the European Union's Seventh Framework Programme (FP/2007-2013)/ERC Grant Agreement n. [313847] 'World Seastems'. The authors would like to thank the editor and anonymous reviewers for their constructive advice, as well as the research assistant, Ellie Chow, for her efforts on data collection and preparation of the manuscript. An earlier version was presented during the Annual Conference of the International Association of Maritime Economists (IAME) 2012 (cf. Ng and Ducruet, 2012). The usual disclaimers apply.

\section{Notes}

1. For example, among the 395 port papers published in various journals between 1997 and 2008 reviewed by Pallis et al. (2010 and 2011), based on our sample (Appendix I), at least 50 papers published within the same period had been overlooked. Among them, only two were published in Journal of Transport Geography, while all the others were published in the more general (human) geography journals.

2. For details on the categorization of research themes, see $\mathrm{Ng}$ (2013). The author gratefully acknowledged the constructive advice from Cesar Ducruet, Kevin O'Connor, Brian Slack and James Wang in the categorization process.

\section{References}

Airriess CA (1989) The spatial spread of container transport in a developing regional economy: North Sumatra, Indonesia. Transportation Research Part A: Policy and Practice 23: 453-461.

Bird J (1977) Centrality and Cities, London: Routledge Direct Editions.

Bretagnolle A, Pumain D and Vacchiani-Marcuzzo C (2009) The organization of urban systems. In: Lane D, Pumain D, Van der Leeuw S and West G (eds) Complexity Perspectives on Innovation and Social Change, ISCOM, Springer, Methodos Series, Berlin, 197-220.

Charlier JJ and Ridolfi G (1994) Intermodal transportation in Europe: of modes, corridors and nodes. Maritime Policy \& Management 21: 237-250.

Ducruet C (2013) Network diversity and maritime flows. Journal of Transport Geography 30: 77-88.

Ducruet C, Ietri D and Rozenblat C (2011) Cities in worldwide air and sea flows: a multiple networks analysis. Cybergeo: European Journal of Geography 528 (online). 
Ducruet C and Lugo I (2013) Structure and dynamics of transportation networks: models, concepts, and applications. In: Rodrigue JP, Notteboom TE and Shaw J (eds) The SAGE Handbook of Transport Studies, SAGE Publications, 347-364.

Ducruet C and Beauguitte L (forthcoming) 'Spatial science' and 'network science': review and outcomes. Networks and Spatial Economics.

Frémont A (2007) Global maritime networks: the case of Maersk. Journal of Transport Geography 15: 431-442.

Friedmann J (1986) The world city hypothesis. Development and Change 17: 69-83.

Goetz AR, Ralston BA, Stutz FP and Leinbach TR (2003) Transportation geography. In: Gaile GL and Willmott CJ (eds) Geography in America at the Dawn of the $21^{\text {st }}$ Century, Oxford: Oxford University Press, 221-236.

Google Scholar Available at: http://scholar.google.com/, last accessed in August 2013.

Gottmann J (1961) Megalopolis, the Urbanized Northeastern Seaboard of the United States, New York: The Twentieth Century Fund.

Hall PV, McCalla RJ, Comtois C and Slack B (2011). Integrating Seaports and Trade Corridors. Ashgate, Aldershot.

Hall PV and Hesse M (2012) Cities, Regions and Flows, Routledge.

Harvey D (2005) A Brief History of Neoliberalism, Oxford: Oxford University Press.

Hayuth Y and Hilling D (1992) Technological change and seaport development. In: Hoyle B and Pinder D (eds) European Port Cities in Transition. Belhaven, London, pp. 4-58.

Heaver TD (2002) The evolving roles of shipping lines in international logistics. International Journal of Maritime Economics 4 : 210-230.

Heaver TD (2006) The evolution and challenges of port economics. In: Cullinane $\mathrm{K}$ and Talley WK (eds) Port Economics. Elsevier, Oxford, 11-41.

Hoare AG (1988) Geographical aspects of British overseas trade: a framework and a review. Environment and Planning A 20: 345-1364.

Hoare AG (1993) Domestic regions, overseas nations, and their interactions through trade: the case of the United Kingdom. Environment and Planning A 25: 701-722.

Hoyle BS and Hilling D (1984) Seaport Systems and Spatial Change: Technology, Industry and Development Strategies. John Wiley \& Sons, New York.

Hoyle BS and Pinder DA (1992) European Port Cities in Transition. London: Belhaven.

$\mathrm{Hu}$ Y and Zhu D (2009) Empirical analysis of the worldwide maritime transportation network. Physica A 388: 2061-2071.

IAME 2011 Conference Website Available at http://www.iame2011.org, last accessed in October 2011.

ISI Web of Knowledge Available at: http://admin-apps.isiknowledge.com, last accessed in March 2012.

Keeling DJ (2007) Transportation geography: new directions on well-worn trails. Progress in Human Geography 31: 217-225.

Keeling DJ (2009) Transportation geography: local challenges, global contexts. Progress in Human Geography 33: 516-526.

Knowles R (2006) Transport shaping space: differential collapse in time-space. Journal of Transport Geography 14: 407-425.

Kuby R, Ratick S and Osleeb J (1991) Modeling US coal export planning decisions. Annals of the Association of American Geographers 81: 627-649.

Kuhn TS (1962) The Structure of Scientific Revolutions. University of Chicago Press, Chicago, IL. 
Marti BE and Krausse GH (1983) Trade route 11: methods to assess port exchanges of maritime containerized cargo flows. Ocean Management 8: 317-333.

Mayer HM (1954) Great Lakes-overseas: an expanding trade route. Economic Geography 30: 117-143.

McCalla RJ (1999) Global change, local pain: intermodal seaport terminals and their service areas. Journal of Transport Geography 7: 247-254.

Meersman H and van de Voorde E (1998) Coping with port competition in Europe: a state of the art. In: Sciutto G and Brebbia CA (eds) Marine Engineering and Ports. WIT Press, Southampton, 281-290.

Newman MEJ (2004) Co-authorship networks and patterns of scientific collaboration. Proceedings of the National Academy of Sciences of the United States of America 101: 5200-5205.

Newman MEJ (2010) Networks: An Introduction. Oxford University Press, Oxford.

$\mathrm{Ng}$ AKY (2006) Assessing the attractiveness of ports in the North European container transshipment market: an agenda for future research in port competition. Maritime Economics \& Logistics 8: 234-250.

Ng AKY (2012) Container liner shipping, port development and competition. In: Song DW and Panayides PM (eds) Maritime Logistics: Contemporary Issues. Emerald, Bingley, $5-28$

$\mathrm{Ng}$ AKY (2013) The evolution and research trends of port geography. The Professional Geographer 65(1): 65-86.

$\mathrm{Ng}$ AKY and Ducruet C (2012) Port geography bibliometrics (1950-2011): community structure, background and diffusion. Proceedings of the Annual Conference of the International Association of Maritime Economists 2012, Taipei, Taiwan, 6-8 September.

$\mathrm{Ng}$ AKY and Liu JJ (2010) The port and maritime industries in the post-2008 world: challenges and opportunities. Research in Transportation Economics 27: 1-3.

$\mathrm{Ng}$ AKY and Pallis AA (2010) Port governance reforms in diversified institutional frameworks: generic solutions, implementation asymmetries. Environment and Planning A 42: 2147-2167.

$\mathrm{Ng}$ AKY and Wilmsmeier G (2012) Editorial - the geography of maritime transportation: space as a perspective in maritime transport research. Maritime Policy \& Management 39: 127-132.

Notteboom TE and Winkelmans W (2001) Structural changes in logistics: how will port authorities face the challenge?. Maritime Policy and Management 28: 71-89.

Notteboom TE and Rodrigue JP (2005) Port regionalization: towards a new phase in port development. Maritime Policy \& Management 32: 297-313.

Notteboom TE, Ducruet C and de Langen PW (2009) Ports in Proximity: Competition and Coordination among Adjacent Seaports. Ashgate, Aldershot.

Olivier D and Slack B (2006) Rethinking the port. Environment and Planning A 38(8): 14091427.

Pallis AA, Vitsounis TK. and de Langen PW (2010) Research in port economics, policy and management: a review. Transport Reviews 30: 115-161.

Pallis AA, Vitsounis TK., de Langen PW and Notteboom TE (2011) Port economics, policy and management: content classification and survey. Transport Reviews 31: 445-471.

Pedersen P (2001) Freight transport under globalisation and its impact on Africa. Journal of Transport Geography 9: 85-99. 
Pinder D and Slack B (2004) Shipping and Ports in the Twenty-First Century: Globalization, Technological Change and the Environment. New York: Routledge.

Riggs LS, McCarragher S and Krmenec A (2012) Authorship, collaboration and gender: fifteen years of publication productivity in selected geography journals. The Professional Geographer 64: 491-502.

Robinson R (2002) Ports as elements in value-driven chain systems: the new paradigm. Maritime Policy \& Management 29: 241-255.

Sager T (2011) Neo-liberal urban planning policies: A literature survey 1990-2010. Progress in Planning 76: 147-200.

Sanchez RJ, Ng AKY and Garcia-Alonso L (2011) Port selection factors and attractiveness: the service suppliers' perspective. Transportation Journal 50:141-161.

Scopus Available at: http://www.scopus.com/home.url, last access in February 2012.

Shaw J and Sidaway JD (2011) Making links: on (re)engaging with transport and transport geography. Progress in Human Geography 35: 502-520.

Slack B (1980) Technology and seaports in the 1980s. Tijdschrift voor Economische en Sociale Geografie 71: 108-113.

Slack B, Comtois C and Sletmo GK (1996) Shipping lines as agents of change in the port industry. Maritime Policy \& Management 23: 289-300.

Slack B (2004) The global imperatives of container shipping. In Pinder D and Slack B (eds) Shipping and Ports in the Twenty-First Century. Routledge, London.

Smith RHT (1970) Concepts and methods in commodity flow analysis. Economic Geography 46:404-416.

Suykens F and van de Voorde E (1998) A quarter of a century of port management in Europe: objectives and tools. Maritime Policy \& Management 25: 251-261.

Taaffe EJ, Morrill RL and Gould PR (1963) Transport expansion in underdeveloped countries: a comparative analysis. Geographical Review 53: 503-529.

Turnbull P (2006) The war on Europe's waterfront - repertoires of power in the port transport industry. British Journal of Industrial Relations 44: 305-326.

Wang C and Ducruet C (2013) Regional resilience and spatial cycles: long-term evolution of the Chinese port system. Tijdschrift voor Economische en Sociale Geografie. DOI: $10.1111 /$ tesg.12033

Wang JJ, Ng AKY and Olivier D (2004) Port governance in China: a review of policies in an era of internationalising port management practices. Transport Policy 11: 237-250.

Wang JJ, Olivier D, Notteboom T and Slack B (2007) Ports, Cities and Global Supply Chains. Aldershot, Ashgate.

Waters NM (2006) Network and nodal indices - measures of complexity and redundancy: a review. In: Reggiani A and Nijkamp P (eds) Spatial Dynamics, Networks and Modelling, Edward Elgar.

Weaver DC (1998) Trade competition and route development in Georgia and the Carolinas, 1740-1900. Journal of Geography 97: 177-191.

Woo SH, Pettit SJ, Kwak DW and Beresford AKC (2011) Seaport research: a structured literature review on methodological issues since the 1980s. Transportation Research Part A: Policy and Practice 45: 667-685. 
Table 1. Distribution of port geography papers by journal and period, 1950-2012

\begin{tabular}{|c|c|c|c|c|c|c|c|c|}
\hline Journal & $1950 \mathrm{~s}$ & $1960 \mathrm{~s}$ & $1970 \mathrm{~s}$ & $1980 \mathrm{~s}$ & 1990s & $2000 \mathrm{~s}$ & $2010 \mathrm{~s}$ & Total \\
\hline Annals of Regional Science & & & & & & 1 & & 1 \\
\hline $\begin{array}{l}\text { Annals of the Association of American } \\
\text { Geographers }\end{array}$ & 19 & 8 & 4 & & & & & 31 \\
\hline Applied Geography & & & & 1 & & 1 & & 2 \\
\hline Area & & & 1 & 1 & 2 & & & 4 \\
\hline Asia Pacific Viewpoint & & & & & 2 & 2 & & 4 \\
\hline Australian Geographer & & 3 & 1 & 2 & 1 & 1 & 1 & 9 \\
\hline Canadian Geographer & 2 & 1 & 1 & 3 & 1 & 4 & & 12 \\
\hline Economic Geography & 5 & 8 & 4 & 2 & 1 & 2 & & 22 \\
\hline Environment \& Planning A & & & & 1 & 1 & 8 & 2 & 12 \\
\hline Environment \& Planning C & & & & 2 & & & & 2 \\
\hline Environment \& Planning D & & & & 1 & 1 & & & 2 \\
\hline Eurasian Geography \& Economics & & & & & & & 1 & 1 \\
\hline European Planning Studies & & & & & 4 & 2 & & 6 \\
\hline Europe-Asia Studies & & & & & & 1 & & 1 \\
\hline Geoforum & & & 2 & 8 & 6 & 4 & & 20 \\
\hline $\begin{array}{l}\text { Geografiska Annaler - Series B: Human } \\
\text { Geography }\end{array}$ & & 1 & 1 & 1 & 1 & & & 4 \\
\hline Geographical Review & 6 & 3 & 2 & 1 & 3 & 2 & & 17 \\
\hline Geography & 8 & 12 & 8 & 4 & 1 & & & 33 \\
\hline GeoJournal & & & 2 & 6 & 10 & 7 & & 25 \\
\hline Global Networks & & & & & & & 2 & 2 \\
\hline $\begin{array}{l}\text { International Journal of Urban \& } \\
\text { Regional Research }\end{array}$ & & & & & & 5 & & 5 \\
\hline Journal of Historical Geography & & & 1 & 1 & & 1 & & 3 \\
\hline Journal of Transport Geography & & & & & 14 & 22 & 24 & 60 \\
\hline Landscape \& Urban Planning & & & & & 1 & & & 1 \\
\hline New Zealand Geographer & & & 1 & & & 1 & & 2 \\
\hline Papers in Regional Science & 1 & & & & & 1 & & 2 \\
\hline Political Geography & & & & & 1 & 1 & & 2 \\
\hline Professional Geographer & & 5 & 2 & 3 & 1 & & & 11 \\
\hline Progress in Human Geography & & & & 1 & & & & 1 \\
\hline Regional Studies & & & 1 & & & 1 & 3 & 5 \\
\hline Scottish Geographical Journal & 3 & 6 & 1 & & & 1 & & 11 \\
\hline The Geographical Journal & & 4 & 2 & & & 1 & & 7 \\
\hline $\begin{array}{l}\text { Tijdschrift voor Economische en Sociale } \\
\text { Geografie }\end{array}$ & 24 & 23 & 4 & 5 & 9 & 6 & 2 & 73 \\
\hline $\begin{array}{l}\text { Transactions of the Institute of British } \\
\text { Geographers }\end{array}$ & & 2 & & & 1 & & & 3 \\
\hline Urban Geography & & & & & & 2 & & 2 \\
\hline Zeitschrift für Wirtschaftsgeographie & & & & & & 1 & & 1 \\
\hline Total & 68 & 76 & 38 & 43 & 61 & 78 & 35 & 399 \\
\hline
\end{tabular}


Table 2: Bibliometric indicators on core port geography papers, 1950-2012

\begin{tabular}{|c|c|c|c|c|}
\hline \multirow{2}{*}{ Period } & \multicolumn{2}{|c|}{$\begin{array}{c}\text { Mean number of authors per } \\
\text { paper }\end{array}$} & \multicolumn{2}{c|}{ Share (\%) of single authored papers } \\
\cline { 2 - 5 } & CPG & EPG & CPG & EPG \\
\hline $1950-1959$ & 1.09 & 1.00 & 83.78 & 100.00 \\
\hline $1960-1969$ & 1.05 & 1.00 & 90.00 & 100.00 \\
\hline $1970-1979$ & 1.11 & 1.08 & 80.95 & 92.31 \\
\hline $1980-1989$ & 1.23 & 1.15 & 66.04 & 84.85 \\
\hline $1990-1999$ & 1.33 & 1.37 & 53.09 & 73.68 \\
\hline $2000-2009$ & 1.67 & 1.92 & 30.77 & 37.27 \\
\hline $2010-2012$ & 2.29 & 2.36 & 6.25 & 17.02 \\
\hline $1950-2012$ & 1.35 & 1.72 & 53.89 & 51.87 \\
\hline
\end{tabular}


Table 3. The research themes of port geography papers published in geography and nongeography journals

\begin{tabular}{|c|c|c|c|c|c|c|c|c|c|c|c|c|c|c|c|c|}
\hline & & 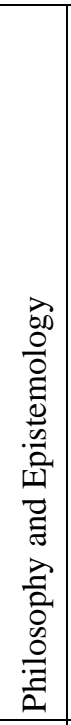 & 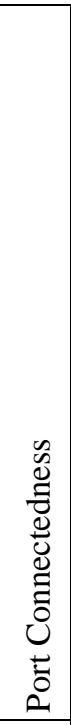 & 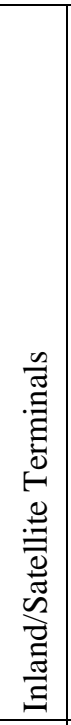 & 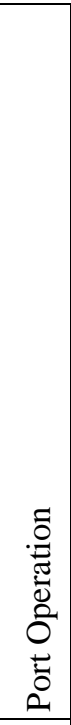 & 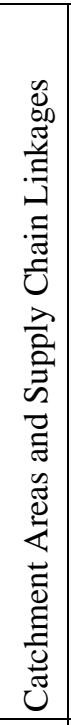 & 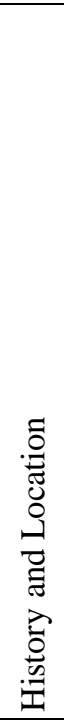 & 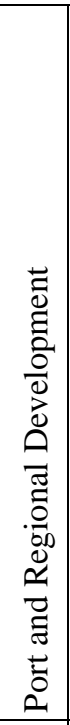 & 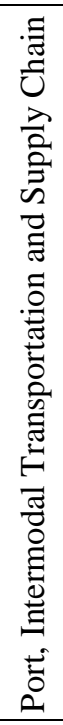 & 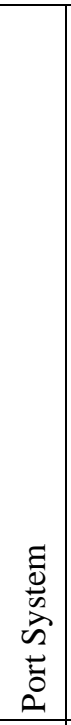 & 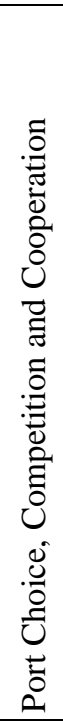 & 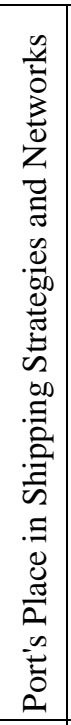 & 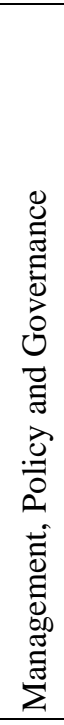 & 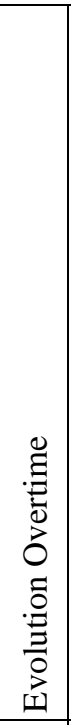 & 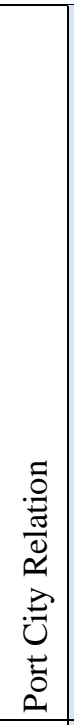 & تేّ \\
\hline \multirow{5}{*}{$\begin{array}{l}\text { Core port } \\
\text { geography }\end{array}$} & 1950-1974 & 10 & 8 & 1 & 2 & 18 & 17 & 18 & 8 & 9 & 3 & 4 & 2 & 49 & 19 & 167 \\
\hline & $1975-1990$ & 0 & 1 & 1 & 4 & 2 & 1 & 10 & 3 & 7 & 1 & 4 & 5 & 8 & 19 & 64 \\
\hline & 1991-2001 & 0 & 0 & 1 & 1 & 1 & 3 & 3 & 4 & 13 & 7 & 4 & 7 & 2 & 24 & 69 \\
\hline & 2002-2012 & 0 & 2 & 5 & 2 & 2 & 6 & 4 & 19 & 11 & 6 & 14 & 8 & 4 & 19 & 99 \\
\hline & Total & 10 & 11 & 7 & 9 & 23 & 26 & 34 & 34 & 39 & 17 & 26 & 22 & 63 & 80 & 399 \\
\hline \multirow{5}{*}{$\begin{array}{l}\text { Extended } \\
\text { port } \\
\text { geography }\end{array}$} & 1950-1974 & 0 & 0 & 0 & 0 & 1 & 3 & 1 & 0 & 0 & 2 & 1 & 6 & 5 & 5 & 24 \\
\hline & 1975-1990 & 0 & 2 & 2 & 1 & 0 & 3 & 3 & 4 & 7 & 7 & 4 & 4 & 8 & 9 & 54 \\
\hline & 1991-2001 & 0 & 1 & 1 & 6 & 1 & 7 & 2 & 4 & 0 & 10 & 10 & 17 & 9 & 27 & 95 \\
\hline & 2002-2012 & 0 & 1 & 10 & 12 & 12 & 0 & 8 & 14 & 10 & 23 & 19 & 20 & 6 & 21 & 156 \\
\hline & Total & 0 & 4 & 13 & 19 & 14 & 13 & 14 & 22 & 17 & 42 & 34 & 47 & 28 & 62 & 329 \\
\hline \multicolumn{2}{|c|}{ Grand total } & 10 & 15 & 20 & 28 & 37 & 39 & 48 & 56 & 56 & 59 & 60 & 69 & 91 & 142 & 728 \\
\hline
\end{tabular}


Figure 1. Production trend: core port geography vs. extended port geography papers, 1950-2012

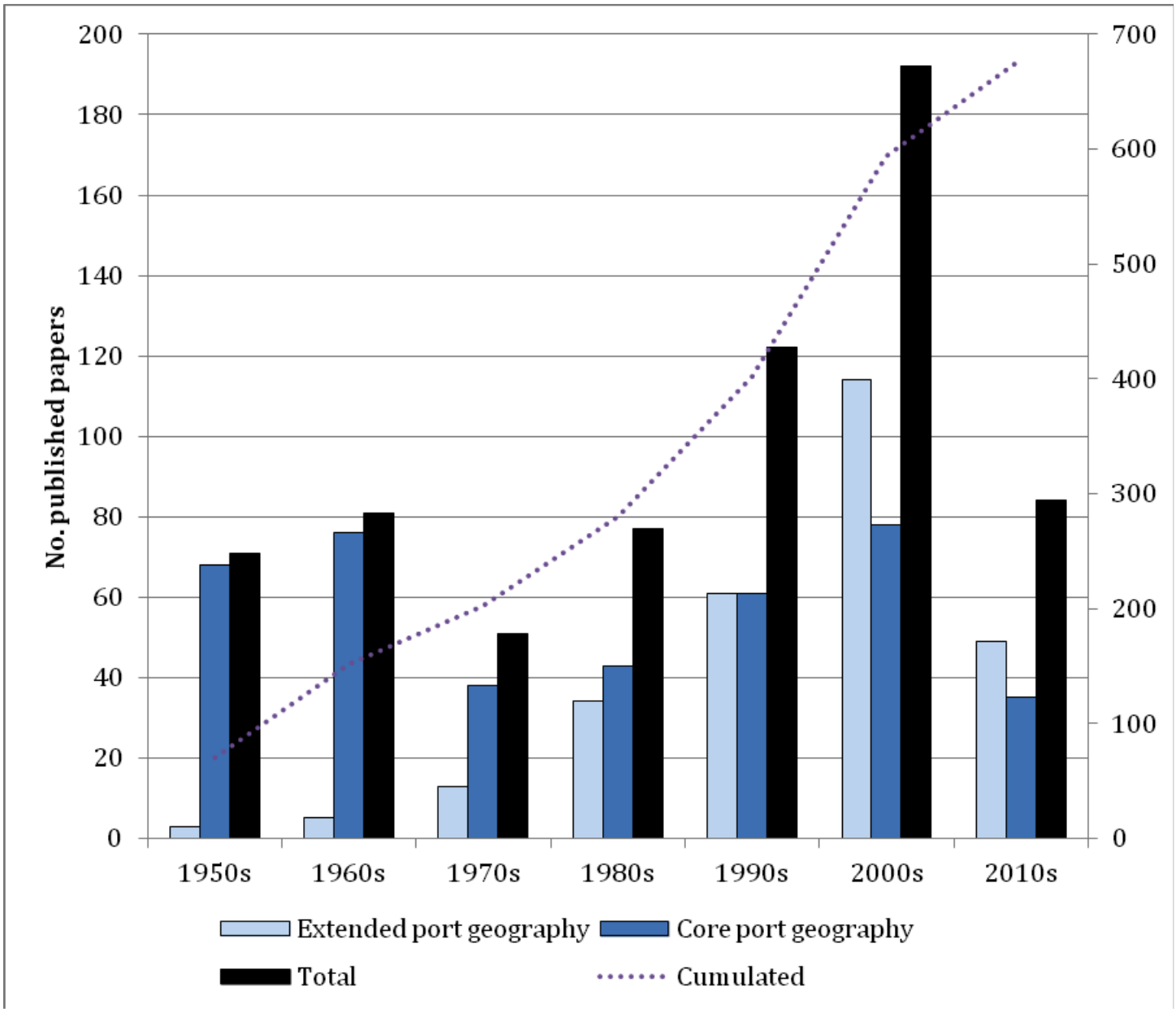


Figure 2. The geographical coverage of port geography papers, 1950-2012

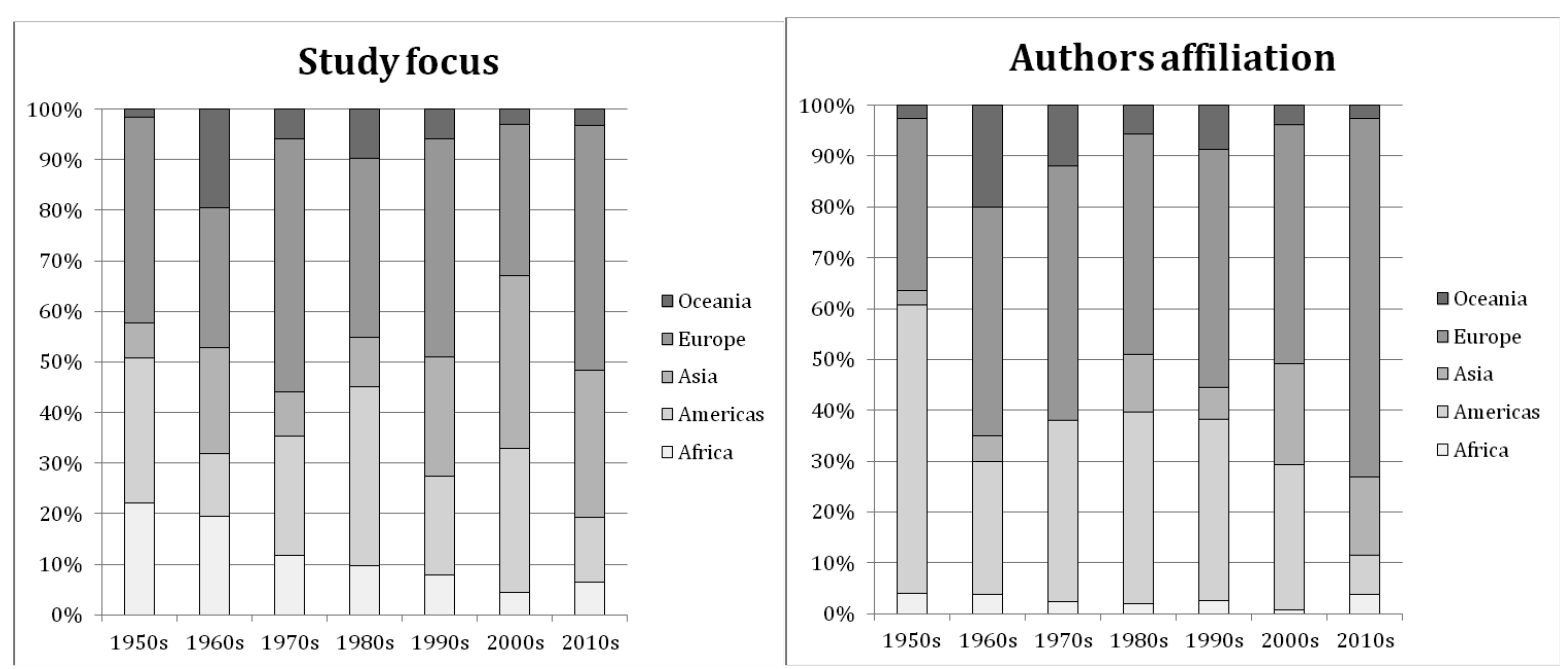


Figure 3. Graph illustrating co-authorships across core port geography papers, 19502012

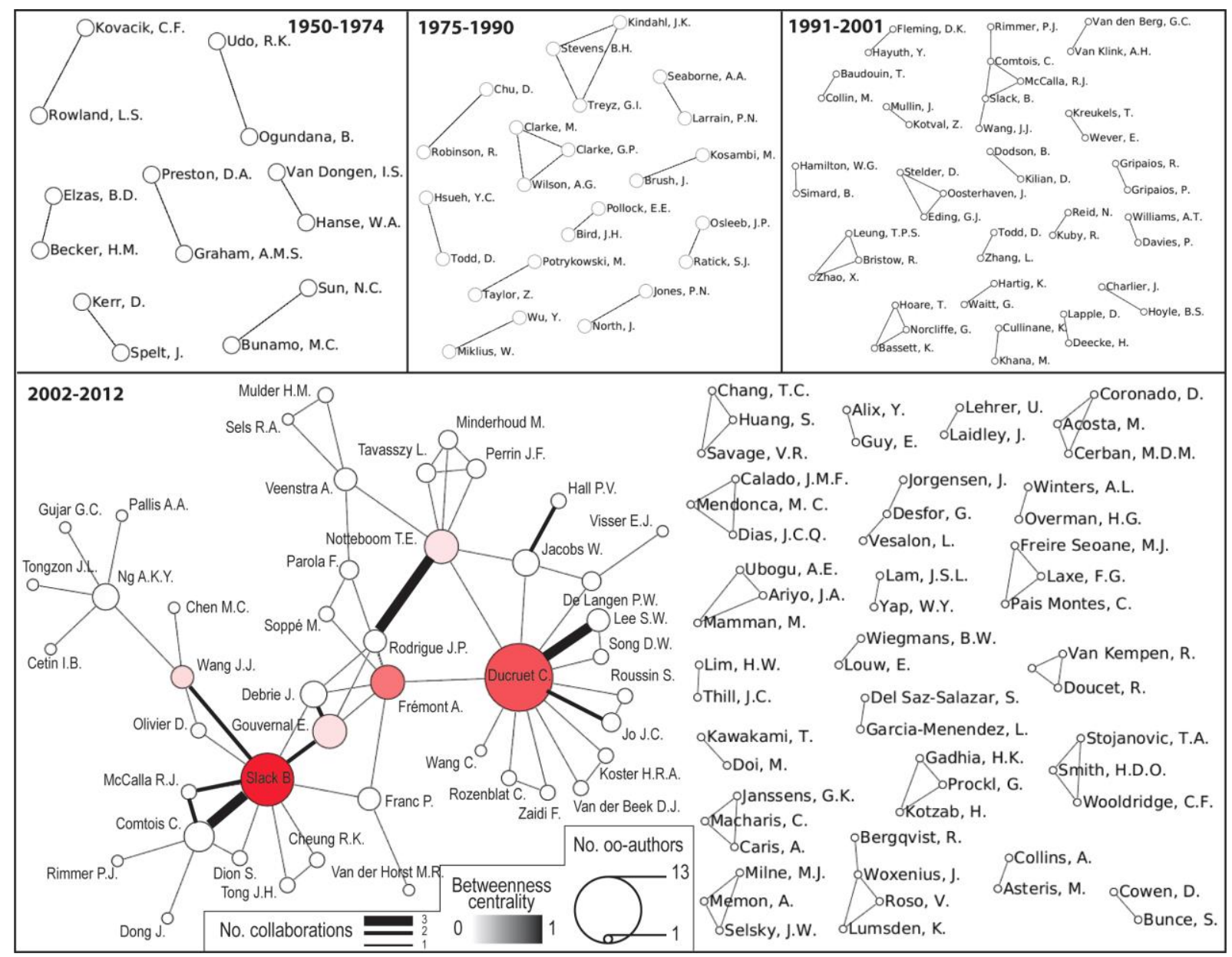


Figure 4. Distribution of journal papers under different disciplines cited by core port geography papers, 1950-2012

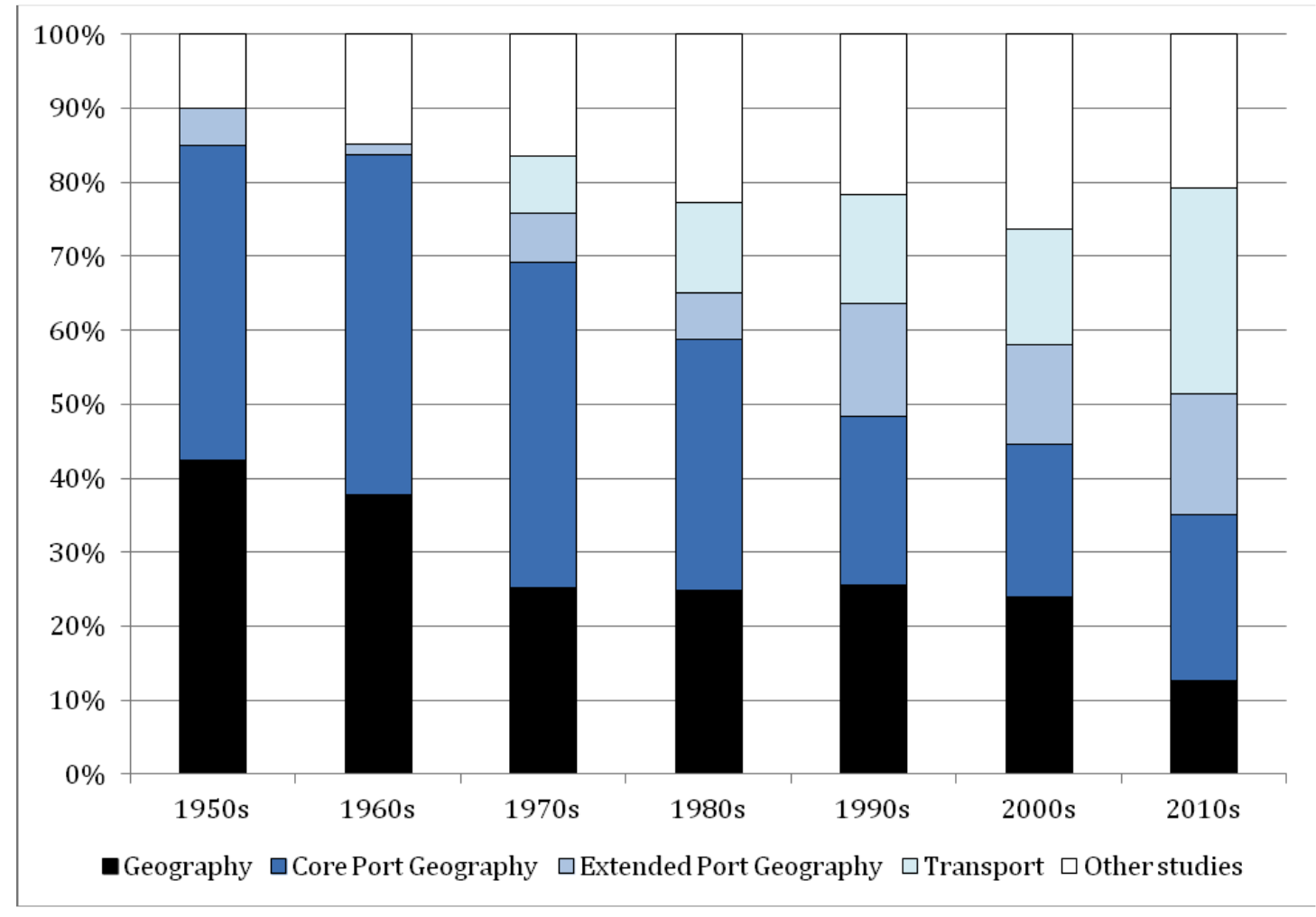


Figure 5. Graph illustrating citations by core port geography papers, 1950-2012

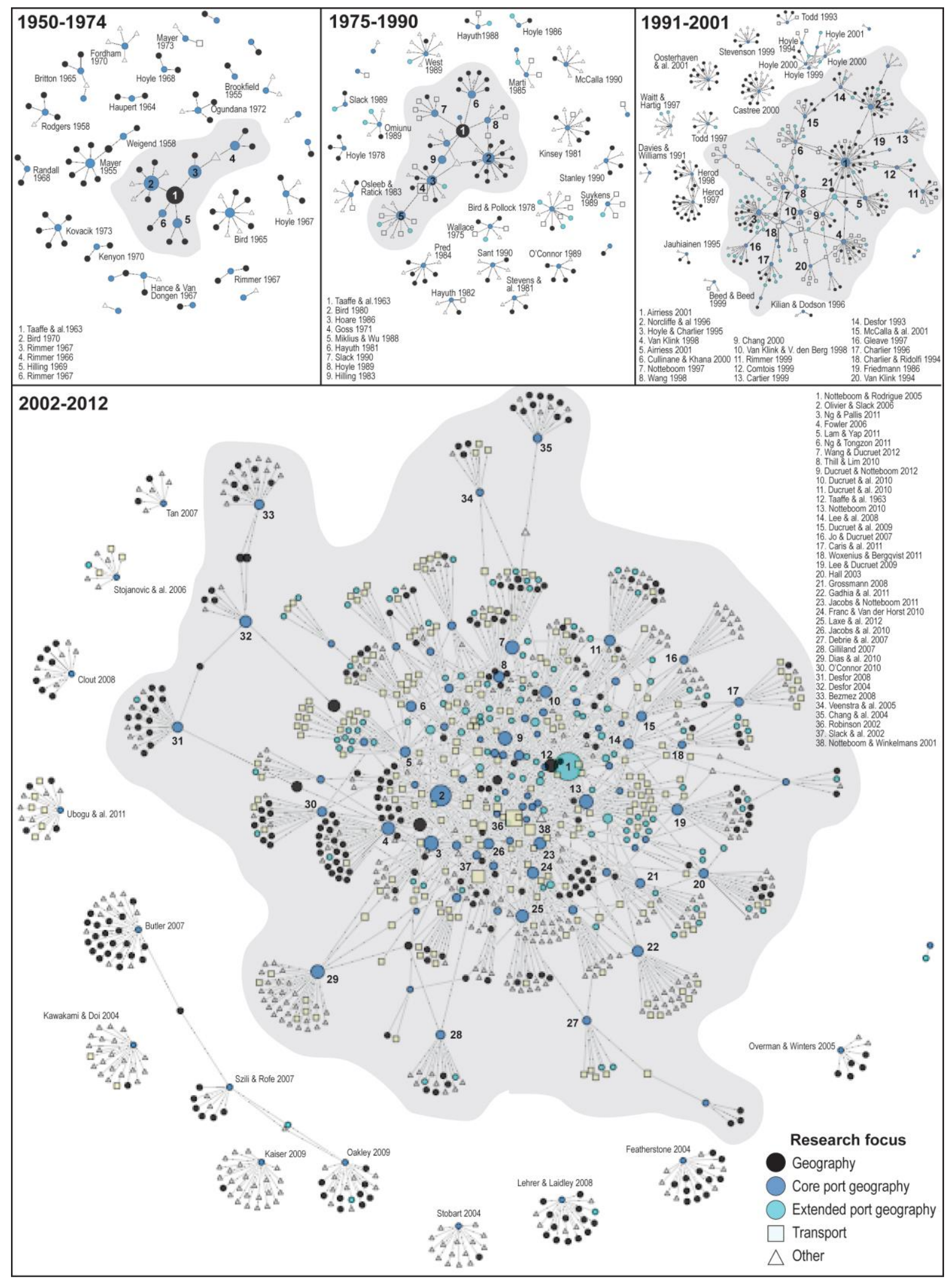


Figure 6. Distribution of papers under different disciplines citing core port geography papers, 1950-2012

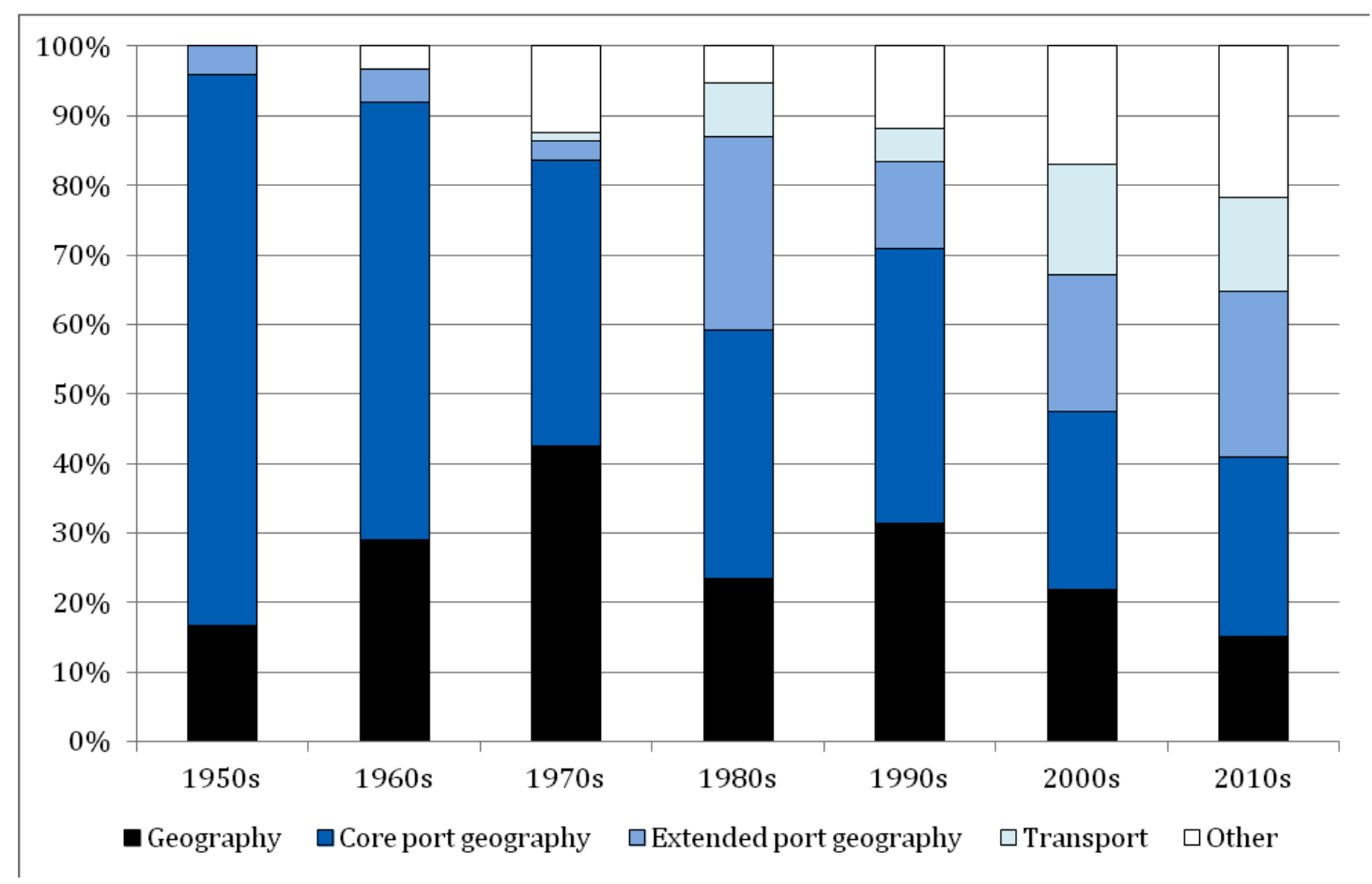


Figure 7. Graph illustrating citations of core port geography papers, 1950-2012

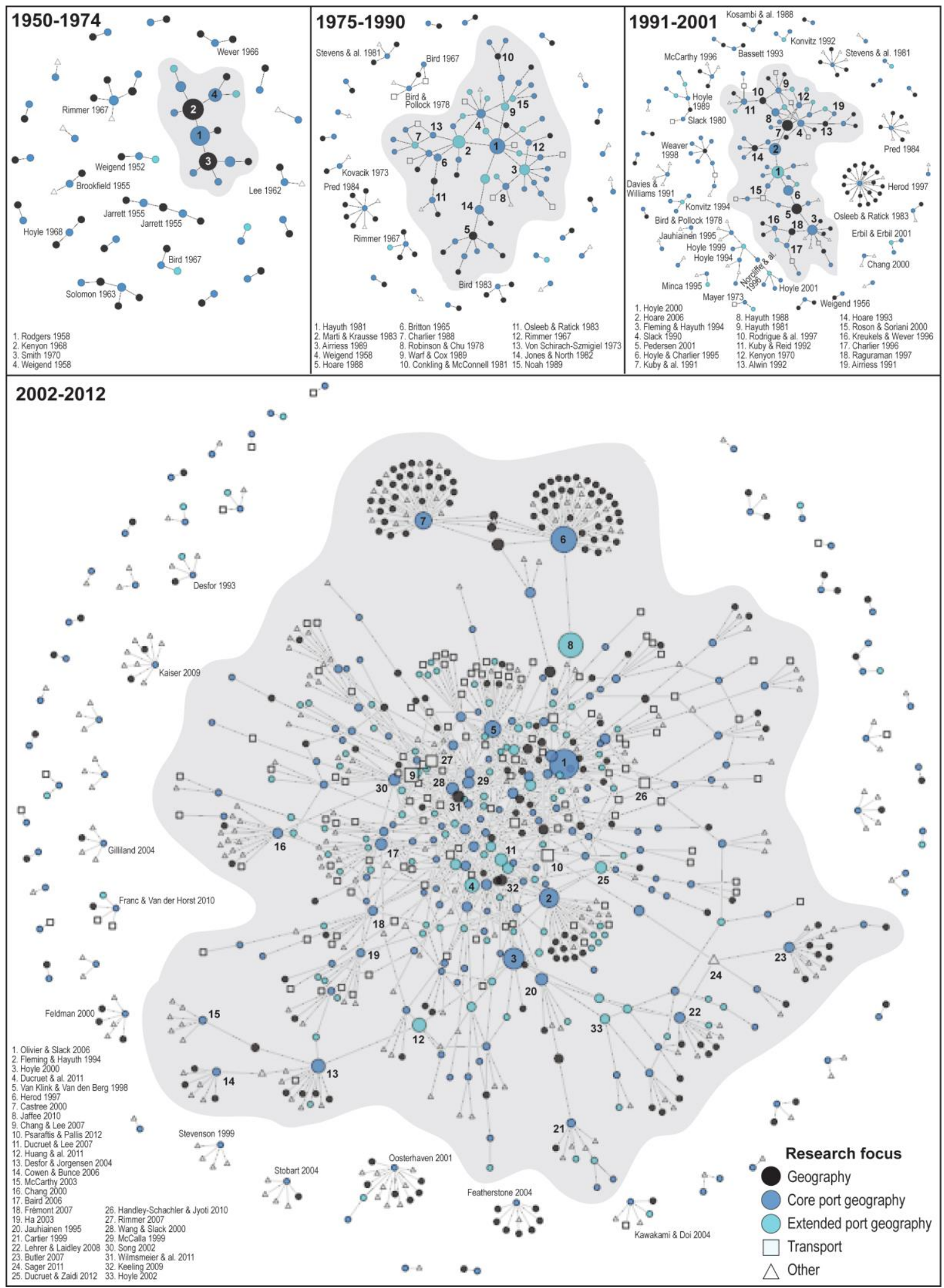




\section{Appendix I}

\section{Port Geography Papers Included in this Study}

1. Acosta M, Coronado D and del mar Cerban M (2011) Bunkering competition and competitiveness at the ports of the Gibraltar Strait. Journal of Transport Geography 19: 911-916.

2. Airriess CA (1991) Global economy and port morphology in Belawan, Indonesia. Geographical Review 81: 183-196.

3. Airriess CA (2001) Regional production, information-communication technology, and the developmental state: the rise of Singapore as a global container hub. Geoforum 32: 235-254.

4. Airriess CA (2001) The regionalization of Hutchison Port Holdings in Mainland China. Journal of Transport Geography 9: 267-278.

5. Andrews JH (1950) The development of the passenger ports of South-East England. Geography 35: 239-243.

6. Andrews JH (1955) Chepstow: a defunct seaport of the Severn estuary. Geography 40: 97-107.

7. Arqued RC (1996) Commercial ports in Spain. Tijdschrift voor Economische en Sociale Geografie 87: 357-363.

8. Asteris M and Collins A (2007) Developing Britain's port infrastructure: markets, policy, and location. Environment and Planning A 39: 2271-2286.

9. Baird AJ (1996) Seaports in the United Kingdom. Tijdschrift voor Economische en Sociale Geografie 87: 322-331.

10. Baird AJ (2006) Optimizing the container transshipment hub location in northern Europe. Journal of Transport Geography 14: 195-214.

11. Ballert AG (1953) The ports and lake trade of Georgian Bay. Annals of the Association of American Geographers 43: 158.

12. Ballert AG (1957) The nature of the Great Lakes port. Annals of the Association of American Geographers 47: 152.

13. Barrington R (1968) The Hamburg 'Outer-Harbour' project and related developments. Tijdschrift voor Economische en Sociale Geografie 59: 106-108.

14. Bassett K (1993) British port privatization and its impact on the port of Bristol. Journal of Transport Geography 1: 255-267.

15. Baudouin T and Collin M (1996) The revival of France's port cities. Tijdschrift voor Economische en Sociale Geografie 87: 342-347.

16. Becker HM and Elzas BD (1967) The port of Vlaardingen: functional and structural development. Tijdschrift voor Economische en Sociale Geografie 58: 292-305.

17. Beckles NI (1968) Textiles and port growth in Dundee. Scottish Geographical Journal 84: 90-98.

18. Bezmez D (2008) The politics of urban waterfront regeneration: the case of Halic (the Golden Horn), Istanbul. International Journal of Urban and Regional Research 32: 815-840.

19. Bird JH (1951) Some geographical aspects of the location of ports in Western Europe. Tijdschrift voor Economische en Sociale Geografie 42: 366-376.

20. Bird JH (1965) The foundation of Australian seaport capitals. Economic Geography 41: 283-299.

21. Bird JH (1967) Seaports and the European Economic Community. The Geographical Journal 133: 302-322. 
22. Bird JH (1969) Traffic flows to and from British seaports. Geography 54: 284-302.

23. Bird JH (1970) Seaports are not aberrant cases. Area 4: 65-68

24. Bird JH (1973) Of central places, cities and seaports. Geography 58: 105-118.

25. Bird JH (1980) Seaports as a subset of gateways for regions: a research survey. Progress in Human Geography 4: 360-370.

26. Bird JH (1983) Gateways: slow recognition but irresistible rise. Tijdschrift voor Economische en Sociale Geografie 74: 196-202.

27. Bird JH and Pollock EE (1978) The future of seaports in the European Communities. The Geographical Journal 144: 23-41.

28. Black JN (1974) Maplin - the case for a seaport. The Geographical Journal 140: 364372.

29. Boerman WE (1951) The need for special examination of particular aspects of port geography. Tijdschrift voor Economische en Sociale Geografie 42: 307-319.

30. Boerman WE (1957) Wirtschaftsgeographische Probleme der Rheinhafen und ihres Hinterlandes. Tijdschrift voor Economische en Sociale Geografie 48: 102-112.

31. Boxer B (1962) Shipping movement and economic growth in Hong Kong, 1957-1958. Annals of the Association of American Geographers 52: 321.

32. Bristow R, Zhao X and Leung TPS (1995) Some consequences and impacts of port development - the Hong Kong case. GeoJournal 37: 525-536.

33. Britton JNH (1961) The development of Port Kembla, N.S.W. Geography 46: 109-112.

34. Britton JNH (1962) The transport functions of the port of Kembla. Economic Geography 38: 357-358.

35. Britton JNH (1965) The external relations of seaports: some new considerations. Tijdschrift voor Economische en Sociale Geografie 56: 109-112.

36. Britton JNH (1965) Coastwise external relations of the ports of Victoria. Australian Geographer 9: 269-281.

37. Broek JOM (1957) The ports of Borneo. Annals of the Association of American Geographers 47: 150-155.

38. Brookfield HC (1955) New railroad and port developments in East and Central Africa. Economic Geography 31(1): 60-70.

39. Brooks JE (1960) Problems of a Riverine Port: Portland, Oregon. Annals of the Association of American Geographers 50: 306.

40. Brown BJH (1977) Expansion problems in the Port of Bristol. Geography 62: 212-215.

41. Brunt B (2000) Ireland's seaport system. Tijdschrift voor Economische en Sociale Geografie 91: 159-175.

42. Butler T (2007) Re-urbanizing London docklands: gentrification, suburbanization or new urbanism?. International Journal of Urban and Regional Research 31: 759- 781.

43. Cambier P (1952) The port of Gent. Tijdschrift voor Economische en Sociale Geografie 43: $189-203$.

44. Camu P (1955) Notes on port studies. Canadian Geographer 2: 51-59.

45. Caris A, Macharis C and Janssens GK (2011) Network analysis of container barge transport in the port of Antwerp by means of simulation. Journal of Transport Geography 19: 125-133.

46. Carter RE (1959) A comparative analysis of United States ports. Annals of the Association of American Geographers 49: 170.

47. Carter RE (1962) A comparative analysis of United States ports and their traffic characteristics. Economic Geography 38: 162-175. 
48. Cartier C (1999) Cosmopolitics and the maritime world city. Geographical Review 89: 278-289.

49. Castree N (2000) Geographic scale and grass-root internationalism: the Liverpool dock dispute, 1995-1998. Economic Geography 76: 272-292.

50. Chang SE (2000) Disasters and transport systems: loss, recovery and competition at the Port of Kobe after the 1995 earthquake. Journal of Transport Geography 8: 53-65.

51. Chang TC, Huang S and Savage VR (2004) On the waterfront: globalization and urbanization in Singapore. Urban Geography 25: 413-436.

52. Chapman EC (1962) Queensland Ports and the bulk shipment of Australian raw sugar. Geography 47(3): 310-313.

53. Charlier J (1996) The Benelux seaport system. Tijdschrift voor Economische en Sociale Geografie 87: 310-321.

54. Chen CS (1957) The port of Keelung. Tijdschrift voor Economische en Sociale Geografie 48: 112-118.

55. Cheung RK, Tong JH and Slack B (2003) The transition from freight consolidation to logistics: the case of Hong Kong. Journal of Transport Geography 11: 245-253.

56. Clarke GP, Clarke M and Wilson AG (1986) Reexamining old problems with new methods: Portbury revisited. Environment and Planning C 4: 353-374.

57. Clout H (1968) Expansion projects for French seaports. Tijdschrift voor Economische en Sociale Geografie 59: 271-277.

58. Clout H (1975) Le Havre-Antifer: a giant channel port. Geoforum 6: 247-274.

59. Clout H (2008) Popular geographies in a French port city: the experience of the Le Havre society of commercial geography, 1884-1948. Scottish Geographical Journal 123: 53-77.

60. Coetzee JA (1963) The Transvaal competitive area and the distribution of its commercial sea-borne imports via the Ports of South Africa and Lourenco Margues. Tijdschrift voor Economische en Sociale Geografie 54(8-9): 186-192.

61. Cole JP (1956) Ports and hinterlands in Peru. Tijdschrift voor Economische en Sociale Geografie 47: 173-177.

62. Comtois C and Rimmer PJ (1996) Refocusing on China: the case of Hutchison Whampoa. Asia Pacific Viewpoint 37: 89-102.

63. Comtois C (1999) The integration of China's port system into global container shipping. GeoJournal 48: 35-42.

64. Comtois C and Dong J (2007) Port competition in the Yangtze River Delta. Asia Pacific Viewpoint 28: 299-311.

65. Cowen D and Bunce S (2006) Competitive cities and secure nations: conflict and convergence in urban waterfront agendas after 9/11. International Journal of Urban and Regional Research 30(2): 427-439.

66. Cullinane K and Khana M (2000) Economies of scale in large containerships: optimal size and geographical implications. Journal of Transport Geography 8: 181-195.

67. Darnton DC (1963) We can have hinterland data. The Professional Geographer 15: 1113.

68. Davies P and Williams AT (1991) The enigma of the destruction of Colhuw Port, Wales. Geographical Review 81: 257-266.

69. Daysh GHJ (1951) Recent industrial trends in certain ports of Northern England. Tijdschrift voor Economische en Sociale Geografie 42: 387-390. 
70. de Langen PW and Visser EJ (2005) Collective action regimes in seaport clusters: the case of the Lower Mississippi port cluster. Journal of Transport Geography 13: 173186.

71. de Nie HJ (1960) The Indus, Karachi and its hinterland. Tijdschrift voor Economische en Sociale Geografie 51(10): 266-273.

72. de Sbarats JM (1971) A geographical analysis of the Clyde's forelands. Tijdschrift voor Economische en Sociale Geografie 62: 249-263.

73. de Sbarats JM (1972) Some geographical aspects of port modernisation: The case of Clydeport. Scottish Geographical Journal 88: 182-195.

74. Debrie J, Gouvernal E and Slack B (2007) Port devolution revisited: the case of regional ports and the role of lower tier governments. Journal of Transport Geography 15: 455-464.

75. Deecke H and Lapple D (1996) German seaports in a period of re-structuring. Tijdschrift voor Economische en Sociale Geografie 87: 332-341.

76. del Saz-Salazar S and Garcia-Menendez L (2003) The nonmarket benefits of redeveloping dockland areas for recreational purposes: the case of Castellón, Spain. Environment and Planning A 35: 2115-2129.

77. Delmer A (1951) La classification des ports. Tijdschrift voor Economische en Sociale Geografie 42 : 325-354.

78. Desfor G (1993) Restructuring the Toronto Harbour Commission: land politics on the Toronto waterfront. Journal of Transport Geography 1: 167-181.

79. Desfor G (2004) Flexible urban governance. The case of Copenhagen's recent waterfront development. European Planning Studies 12: 479-496.

80. Desfor G (2008) Urban expansion and industrial nature: A political ecology of Toronto's port industrial district. International Journal of Urban and Regional Research 32: 586-603.

81. Dias JCQ, Calado JMF and Mendonca MC (2010) The role of European «ro-ro» port terminals in the automotive supply chain management. Journal of Transport Geography 18: 116-124.

82. Dickson KB (1965) Evolution of seaports in Ghana: 1800-1928. Annals of the Association of American Geographers 55: 98-109.

83. Dillman CD. (1969) Brownsville: Border Port for Mexico and the U.S. The Professional Geographer 21: 178-183.

84. Dion S, Slack B and Comtois C (2002) Port and airport divestiture in Canada: a comparative analysis. Journal of Transport Geography 10: 187-193.

85. Doucet B, Van Kempen R and Van Weesep J (2011) Resident perceptions of flagship waterfront regeneration: the case of the Kop Van Zuid in Rotterdam. Tijdschrift voor Economische en Sociale Geografie 102: 125-145.

86. Ducruet C and Lee SW (2006) Frontline soldiers of globalization: Port-city evolution and regional competition. GeoJournal 67: 107-122.

87. Ducruet C, Roussin S and Jo JC (2009) Going west? Spatial polarization of the North Korean port system. Journal of Transport Geography 17: 357-368.

88. Ducruet C, Rozenblat C and Zaidi F (2010) Ports in multi-level maritime networks: evidence from the Atlantic (1996-2006). Journal of Transport Geography 18: 505-518.

89. Ducruet C, Koster HRA and van der Beek BJ (2010) Commodity variety and seaport performance. Regional Studies 44: 1221-1240. 
90. Ducruet C and Notteboom TE (2012) The worldwide maritime network of container shipping: spatial structure and regional dynamics. Global Network 12: 395-423.

91. Dutt AK (1971) Delineation of the hinterland of Calcutta port. The Professional Geographer 23: 22-27.

92. Dwyer DJ (1963) The recent development of the port of Hong Kong. Geography 48: 317-320.

93. Edwards KC (1951) Grimsby and Immingham: a port study. Tijdschrift voor Economische en Sociale Geografie 42: 382-386.

94. Elliot NR (1962) Tyneside, a study in the development of an industrial seaport I. Tijdschrift voor Economische en Sociale Geografie 53: 225-237.

95. Elliot NR (1962) Tyneside, a study in the development of an industrial seaport II. Tijdschrift voor Economische en Sociale Geografie 53: 263-272.

96. Elliot NR (1969) Hinterland and foreland as illustrated by the Port of the Tyne. Transactions of the Institute of British Geographers 47: 153-170.

97. Featherstone D (2004) Spatial relations and the materialities of political conflict: the construction of entangled political identities in the London and Newcastle Port Strikes of 1768. Geoforum 35: 701-711.

98. Feldman M (2000) Urban waterfront regeneration and local governance in Tallinn. Europe-Asia Studies 52: 829-850.

99. Fetherston R (1984) Port developments at Esbjerg. Geography 69: 266-267.

100. Fleming DK (1967) Port geography from Madison Avenue. The Professional Geographer 19: 9-11.

101. Fleming DK (1989) Identification of the shipping district in New York, Houston and Seattle: 1956 and 1987. Geoforum 20: 469-485.

102. Fleming DK and Hayuth Y (1994) Spatial characteristics of transportation hubs: centrality and intermediacy. Journal of Transport Geography 2: 3-18.

103. Fordham RC (1970) The effect of port development upon a major airport at Foulness. Regional Studies 4: 97-106.

104. Forward CN (1967) Recent changes in the form and function of the port of St. John's Newfoundland. Canadian Geographer 11: 101-116.

105. Forward CN (1969) A comparison of waterfront land use in four Canadian ports; St. John's, Saint John, Halifax, and Victoria. Economic Geography 45: 155-169.

106. Forward CN (1970) Waterfront land use in the six Australian state capitals. Annals of the Association of the American Geographers 60: 517-532.

107. Foscue EJ (1957) The ports of Texas and their hinterlands. Tijdschrift voor Economische en Sociale Geografie 48: 1-14.

108. Fowler CS (2006) Re-exploring transport geography and networks: a case study of container shipments to the West Coast of the United States. Environment and Planning A 38: 1429-1448.

109. Franc $P$ and van der Horst $M$ (2010) Understanding hinterland service integration by shipping lines and terminal operators: a theoretical and empirical analysis. Journal of Transport Geography 18: 557-566.

110. Frémont A and Ducruet C (2005) The emergence of a mega-port - from the global to the local: the case of Busan. Tijdschrift voor Economische en Sociale Geografie 96: 421-432.

111. Frémont A (2007) Global maritime networks: the case of Maersk. Journal of Transport Geography 15: 431-442. 
112. Frémont A and Franc P (2010) Hinterland transportation in Europe: combined transport versus road transport. Journal of Transport Geography 18: 548-556.

113. Fuller GJ (1959) Communications in the port of New York. Geography 44: 128-130.

114. Gadhia HK, Kotzab H and Prockl G (2011) Levels of internationalization in the container shipping industry: an assessment of the port networks of the large container shipping companies. Journal of Transport Geography 19: 1431-1442.

115. Gilb CL (1992) Factors contributing to change in the European port system. Landscape and Urban Planning 22: 205-217.

116. Gilliland J (2004) Muddy shore to modern port: re-dimensioning the Montreal waterfront time-space. Canadian Geographer 48: 448-472.

117. Gleave MB (1997) Port activities and the spatial structure of cities: the case of Freetown, Sierra Leone. Journal of Transport Geography 5: 257-275.

118. Gottmann J (1951) Baltimore: un grand port industriel. Tijdschrift voor Economische en Sociale Geografie 42: 360-366.

119. Gould P (1963) Dar es Salaam: the port as a transportation constraint. Annals of the Association of American Geographers 53: 592-593.

120. Gouvernal E, Slack B and Franc P (2010) Short sea and deep sea shipping markets in France. Journal of Transport Geography 18: 97-103.

121. Graham AMS and Preston DA (1961) The new railway and port in Northern Ecuador. Geography 46: 245-247.

122. Gripaios P and Gripaios R (1994) An examination of the case for the extension of port facilities in South West England. Area 26: 377-386.

123. Grossmann I (2008) Perspectives for Hamburg as a port city in the context of a changing global environment. Geoforum, 39: 2062-2072.

124. Guy E and Alix Y (2007) A successful upriver port? Container shipping in Montreal. Journal of Transport Geography 15: 46-55.

125. Ha MS (2003) A comparison of service quality at major container ports: implications for Korean ports. Journal of Transport Geography 11: 131-137.

126. Hall PV (2003) Regional institutional transformation: reflections from the Baltimore Waterfront. Economic Geography 79: 347-363.

127. Hall PV (2004) Mutual specialization, seaports and the geography of automobile imports. Tijdschrift voor Economische en Sociale Geografie 95: 135-146.

128. Hall PV (2009) Container ports, local benefits and transportation worker earnings. GeoJournal 74: 67-83.

129. Hall PV and Jacobs W (2010) Shifting proximities: the maritime ports sector in an era of global supply chains. Regional Studies 44: 1103-1115.

130. Hamilton WG and Simard B (1993) Victoria's inner harbor 1967-1992: the transformation of a deindustrialized waterfront. Canadian Geographer 37: 365-371.

131. Hanrath RE (1960) Port development in Japan, Tijdschrift voor Economische en Sociale Geografie 51: 75-76.

132. Hanse WA (1957) Nacala, newest Mozambique gateway to interior Africa. Tijdschrift voor Economische en Sociale Geografie 47: 307-335.

133. Hanse WA and Van Dongen IS (1956) The port of Lobito and the Benguela railway. Geographical Review 46: 460-487.

134. Hanse WA and Van Dongen IS (1957) Beira, Mozambique gateway to central Africa. Annals of the Association of American Geographers 47: 307-335. 
135. Hanse WA and Van Dongen IS (1957) Lourenco Marques in Delagoa Bay. Economic Geography 33: 238-256.

136. Hanse WA and Van Dongen IS (1958) Dar es Salaam, the port and its tributary area. Annals of the Association of American Geographer 48: 419-435.

137. Hanse WA and Van Dongen IS (1958) Matadi, focus of Belgian African transport. Annals of the Association of American Geographers 48: 41-72.

138. Hanse WA and Van Dongen IS (1961) Gabon and its main gateways: Libreville and Port Gentil. Tijdschrift voor Economische en Sociale Geografie 52: 286-295.

139. Harkema RC The hinterland of Zanzibar in the second half of the $19^{\text {th }}$ century. Tijdschrift voor Economische en Sociale Geografie 55(2): 12-18.

140. Harrison W (1974) The fate of crude oil spills and the siting of four supertanker ports. Canadian Geographer 18: 211-231.

141. Harrison Church RJ (1962) Port Étienne: a Mauritanian pioneer town. The Geographical Journal 128: 498-504.

142. Haupert JS (1964) Development of Israel's frontier port of Elat. The Professional Geographer 16: 13-16.

143. Hayuth Y (1981) Containerization and the load center concept. Economic Geography 57: $160-176$.

144. Hayuth Y (1982) The port-urban interface: an area in transition. Area 14: 219-224.

145. Hayuth Y (1982) Intermodal transportation and the hinterland concept. Tijdschrift voor Economische en Sociale Geografie 73: 13-21.

146. Hayuth Y (1988) Rationalization and deconcentration of the US container port system. The Professional Geographer 40: 279-288.

147. Herod A (1997) Labor's spatial praxis and the geography of contract bargaining in the US East Coast longshore industry, 1953-89. Political Geography 16: 145-169.

148. Herod A (1998) Discourse on the docks: containerization and inter-union work disputes in US ports, 1955-85. Transactions of the Institute of British Geographers 23: 177-191.

149. Hilling D (1966) Tema - the geography of a new port. Geography 51: 111-125.

150. Hilling D (1969) The evolution of the major ports of West Africa. The Geographical Journal 135: 365-378.

151. Hilling D (1977) The evolution of a port system - the case of Ghana. Geography 62: 97105.

152. Hilling D (1983) Ships, ports and developing countries. Geoforum 14: 333-340.

153. Hilling D (1989) Technology and the changing port system of England and Wales. Geography 74: 117-127.

154. Hindle P (1966) Aqaba: an old port revived. The Geographical Journal 132: 64-68.

155. Hoare AG (1986) British ports and their export hinterlands: a rapidly changing geography. Geografiska Annaler - Series B: Human Geography 68: 29-40.

156. Hodder BU (1959) The growth of trade at Lagos, Nigeria. Tijdschrift voor Economische en Sociale Geografie 50(10): 197-202.

157. Hoekman JB (1959) The economic-geographical base of the Port of Delfzijl. Tijdschrift voor Economische en Sociale Geografie 50: 72-78.

158. Hoyle BS (1960) The Etang de Berre: recent port expansion and associated industrial development at Marseilles. Tijdschrift voor Economische en Sociale Geografie 51: 5765 . 
159. Hoyle BS (1967) Early port development in East Africa: an illustration of the concept of changing port hierarchies. Tijdschrift voor Economische en Sociale Geografie 58: 94-102.

160. Hoyle BS (1968) East African seaports: an application of the concept of 'anyport'. Transactions of the Institute of British Geographers 44: 163-183.

161. Hoyle BS (1978) African politics and port expansion at Dar es Salaam. Geographical Review 68: 31-80.

162. Hoyle BS (1984) Ports and hinterlands in an agricultural economy: the case of the Australian sugar industry. Geography 69: 303-316.

163. Hoyle BS (1986) Transport and economic development in the less-developed countries: some reflections on the seaports of Kenya and Tanzania. GeoJournal 12: 233-242.

164. Hoyle BS (1989) The port-city interface: trends, problems and examples. Geoforum. 20:429-435.

165. Hoyle BS (1990) Beyond the waterfront. Area 22: 194-196.

166. Hoyle BS (1993) Water transport and urban development: some geographical perspectives and propositions. GeoJournal 31: 439-448.

167. Hoyle BS (1994) A rediscovered resource: comparative Canadian perceptions of waterfront redevelopment. Journal of Transport Geography 2: 19-29.

168. Hoyle BS (1999) Scale and sustainability: the role of community groups in Canadian port-city waterfront change. Journal of Transport Geography 7: 65-78.

169. Hoyle BS (2000) Global and local change on the port-city waterfront. Geographical Review 90: 395-417.

170. Hoyle BS (2000) Confrontation, consultation, cooperation? Community groups and urban change in Canadian port-city waterfronts. Canadian Geographer 44: 228-243.

171. Hoyle BS (2000) Revitalizing the port-city waterfront: retrospect and prospect. Geographical Review 90: 395-417.

172. Hoyle BS (2001) Urban renewal in East African port cities: Mombasa's old town waterfront. GeoJournal 53: 183-197.

173. Hoyle BS (2002) Urban waterfront revitalization in developing countries: the example of Zanzibar's Stone Town. The Geographical Journal 168: 141-162.

174. Hoyle BS and Charlier J (1995) Inter-port competition in developing countries: an East African case study. Journal of Transport Geography 3: 87-103.

175. Hughes AM (1979) The future of gulf ports. Geography 64: 54-56.

176. Jacobs W (2007) Port competition between Los Angeles and Long Beach. Tijdschrift voor Economische en Sociale Geografie 98: 360-372.

177. Jacobs W and Hall PV (2007) What conditions supply chain strategies of ports? The case of Dubai. GeoJournal 68: 327-342.

178. Jacobs W, Ducruet C and de Langen PW (2010) Integrating world cities into production networks: the case of Port Cities. Global Networks 10: 92-113.

179. Jacobs W and Notteboom TE (2011) An evolutionary perspective on regional port systems: the role of windows of opportunity in shaping seaport competition. Environment and Planning A 43: 1674-1692.

180. Jarrett HR (1951) Bathurst: port of the Gambia River. Geography 36: 98-107.

181. Jarrett HR (1955) The port and town of Freetowm. Geography 40: 108-118.

182. Jarrett HR (1955) Recent port and harbour developments at Freetown. Scottish Geographical Journal 71: 157-164. 
183. Jauhiainen JS (1995) Waterfront redevelopment and urban policy: the case of Barcelona, Cardiff and Genoa. European Planning Studies 3: 3-23.

184. Jo JC and Ducruet C (2007) Rajin-Seonbong, new gateway of Northeast Asia. Annals of Regional Science 41: 927-950.

185. Jones PN and North J (1982) Unit loads through Britain's ports: a further revolution?. Geography 67: 29-40.

186. Kaiser MF (2009) Environmental changes, remote sensing, and infrastructure development: The case of Egypt's East Port Said harbor. Applied Geography 29: 280288.

187. Karmon Y (1963) Eilath, Israel's Red Sea Port. Tijdschrift voor Economische en Sociale Geografie 50: 117-126.

188. Karmon Y (1966) Ashdod: a new Mediterranean port on Israel. Geography 51: 254-258.

189. Kawakami T and Doi M (2004) Port capital formation and economic development in Japan: A vector auto-regression approach. Papers in Regional Science 83: 723-732.

190. Kerr D and Spelt J (1956) Overseas trade at the port of Toronto. Canadian Geographer 2: $70-79$.

191. Keyon JB (1970) Elements in inter-port competition in the United States. Economic Geography 46: 70-124.

192. Kilian D and Dodson B (1996) Between the devil and the deep blue sea: functional conflicts in Cape Town's Victoria and Alfred Waterfront. Geoforum 27: 495-507.

193. Kinniburgh IAG (1960) Greenock: growth and change in the harbours of the town. Scottish Geographical Journal 76: 89-98.

194. Kinniburgh IAG (1960) John Ainslie's map of Port Glasgow in 1806. Scottish Geographical Journal 76(1): 23-24.

195. Kinniburgh IAG (1960) New development in Clydeport. Scottish Geographical Journal.

196. Kinsey J (1981) The economic impact of the port of Liverpool on the economy of Merseyside - using a multiplier approach. Geoforum, 12: 331-347.

197. Kish G (1961) The industrial geography of the port of Genoa. Geographical Review 51: 585-586.

198. Konings R (2007) Opportunities to improve container barge handling in the port of Rotterdam from a transport network perspective. Journal of Transport Geography 15: 443-454.

199. Kormoss IBF (1956) Ostende et les courants de trafic voyageur inter-europeens. Tijdschrift voor Economische en Sociale Geografie 47: 301-311.

200. Kosambi M and Brush J (1988) Three colonial port cities in India. Geographical Review 78: 32-47.

201. Kovacik CF and Rowland LS (1973) Images of colonial Port Royal, South Carolina. Annals of the Association of American Geographers 63: 331-340.

202. Kreukels T and Wever E (1996) Dealing with competition: the port of Rotterdam. Tijdschrift voor Economische en Sociale Geografie 87: 293-309.

203. Krug P (1964) The development of Odessa as a port and trading centre. Tijdschrift voor Economische en Sociale Geografie 55(5): 134-135.

204. Kuby R and Reid N (1992) Technological change and the concentration of the US general cargo port system: 1970-1988. Economic Geography 68: 272-289.

205. Kuipers H (1962) The changing landscape of the Island of Rozenburg (Rotterdam Port Area). Geographical Review 52: 362-378. 
206. Lam JSL (2011) Patterns of maritime supply chains: slot capacity analysis. Journal of Transport Geography 19: 366-374.

207. Lam JSL and Yap WY (2011) Dynamics of liner shipping network and port connectivity in supply chain systems: analysis on East Asia. Journal of Transport Geography 19: 1272-1281.

208. Laxe FG and Freire Seoane MJ (2012) Maritime degree, centrality and vulnerability: port hierarchies and emerging areas in containerized transport (2008-2010). Journal of Transport Geography 24: 33-44.

209. Lee SW, Song DW and Ducruet C (2008) A tale of Asia's world ports: the spatial evolution in global hub port cities. Geoforum 39: 372-385.

210. Lee SW and Ducruet C (2009) Spatial globalization in Asia-Pacific hub port cities: a comparison of Hong Kong and Singapore. Urban Geography 30: 162-184.

211. Lee YL (1962) The port towns of British Borneo. Australian Geographer 8: 161-172.

212. Lehrer U and Laidley J (2008) Old mega-projects newly packaged? Waterfront redevelopment in Toronto. International Journal of Urban and Regional Research 32: 786-803.

213. Loeben AF (1957) Philadelphia Waterfront Industry. Geographical Review 47: 272-273.

214. Marcadon J (1993) Recent maritime research projects on the Lower Loire area. Journal of Transport Geography 1: 268-273.

215. Marcardon J (1999) Containerization in the ports of Northern and Western Europe. GeoJournal 48: 15-20.

216. Marti BE (1985) Chilean ports: commodity specialization and potential for containerization. The Professional Geographer 37: 320-328.

217. Marti BE (1986) Marketing strategies: a container foreland study of the port of Miami. Geoforum 17: 375-382.

218. Maxwell IS (1957) The development of the ports of East Pakistan. Geography 42: 6166.

219. Mayer HM (1955) Prospects and problems of the port of Chicago. Economic Geography 31: 95-125.

220. Mayer HM (1973) Some geographic aspects of technological change in maritime transportation. Economic Geography 49: 145-155.

221. Mayer HM (1978) Current trends in Great Lakes shipping. GeoJournal 2: 117-122.

222. McCalla RJ (1983) Separation and specialization of land uses in cityport waterfronts: the cases of Saint John and Halifax. Canadian Geographer 27: 48-61.

223. McCalla RJ (1990) The geographical spread of free zones associated with ports. Geoforum 21: 121-134.

224. McCalla RJ (1998) An investigation into site and situation: cruise ship ports. Tijdschrift voor Economische en Sociale Geografie 89: 44-55.

225. McCalla RJ (1999) From St. John's to Miami: containerization at eastern seaboard ports. GeoJournal 48: 21-28.

226. McCalla RJ (1999) Global change, local pain: intermodal seaport terminals and their service areas. Journal of Transport Geography 7: 247-254.

227. McCalla RJ (2001) Intermodal freight terminals: locality and industrial linkages. Canadian Geographer 45: 405-413.

228. McCalla RJ (2004) Dealing with globalization at the regional and local level: the case of contemporary containerization. Canadian Geographer 48: 473-487 
229. McCalla RJ (2008) Container transshipment at Kingston, Jamaica. Journal of Transport Geography 16: 182-190.

230. McCalla RJ (2008) Site and situation factors in transshipment ports: the case of the Caribbean Basin. Tijdschrift voor Economische en Sociale Geografie 99: 440- 453.

231. McCarthy J (1996) Waterfront regeneration in the Netherlands: the cases of Rotterdam and Maastricht. European Planning Studies 4: 545-560.

232. McCarthy J (1998) Waterfront regeneration: recent practice in Dundee. European Planning Studies 6: 731-736.

233. McCarthy J (2003) The cruise industry and port city regeneration: the case of Valletta. European Planning Studies 11:341-350.

234. McFarlane M (1961) Developments in Southland, New Zealand. The port of Bluff. Geography 46: 250-252.

235. Memon A and Milne MJ (2004) Restructuring governance of New Zealand seaports: geographical impacts of corporatization. New Zealand Geographer 60: 15-27.

236. Miklius $\mathrm{W}$ and $\mathrm{Wu}$ Y (1988) Forecasting the demand for services of a new port. GeoJournal 16: 295-300.

237. Mills DG (1974) Recent changes in the port of London. Geography 59: 336-339.

238. Mills DG (1978) Changes in the port of Amsterdam. Geography 63: 209-213.

239. Minca C (1995) Urban waterfront evolution: the case of Trieste. Geography 80: 225234.

240. Morgan W (1951) Observations on the study of hinterlands in Europe. Tijdschrift voor Economische en Sociale Geografie 42: 366-375.

241. Mullin J and Kotval Z (1996) The harbour at Viana do Castelo in Portugal: planning in a vacuum. European Planning Studies 4: 131-146.

242. Murphey R (1963) Urbanization and the Western impact in East Asia: the treaty-port phenomenon. Annals of the Association of Americans Geographers 53: 612.

243. Ng AKY and Cetin IB (2012) Locational characteristics of dry ports in developing economies: some lessons from Northern India. Regional Studies 46(6): 757-773.

244. Ng AKY and Gujar GC (2009) The spatial characteristics of inland transport hubs: evidences from Southern India. Journal of Transport Geography 17: 346-356.

245. Ng AKY and Pallis AA (2010) Port governance reforms in diversified institutional frameworks: generic solutions, implementation asymmetries. Environment and Planning A 42: 2147-2167.

246. Ng AKY and Tongzon JL (2010) The transportation sector of India's economy: dry ports as catalysts for regional development. Eurasian Geography and Economics 51: 669-682.

247. Norcliffe G, Bassett K and Hoare T (1996) The emergence of postmodernism on the urban waterfront. Journal of Transport Geography 4: 123-134.

248. Notteboom TE (1997) Concentration and load centre development in the European container port system. Journal of Transport Geography 5: 99-115.

249. Notteboom TE (2006) Traffic inequality in seaport systems revisited. Journal of Transport Geography 14: 95-408.

250. Notteboom TE (2007) Container river services and gateway ports: similarities between the Yangtze River and the Rhine River. Asia Pacific Viewpoint 48: 330-343.

251. Notteboom TE (2007) Spatial dynamics in the container load centres of the Le HavreHamburg range. Zeitschrift für Wirtschaftsgeographie 52: 108-123. 
252. Notteboom TE (2009) Complementarity and substitutability among adjacent gateway ports. Environment and Planning A 41: 743-762.

253. Notteboom TE (2010) Concentration and the formation of multi-port gateway regions in the European container port system: an update. Journal of Transport Geography 18: 567-583.

254. Notteboom TE (2012) Towards a new intermediate hub region in container shipping? Relay and interlining via the Cape route vs. the Suez route. Journal of Transport Geography 22: 164-178.

255. Nowland JL (1961) The port of Istanbul. Scottish Geographical Journal 77: 67-74.

256. Oakley S (2009) Governing urban waterfront renewal: the politics, opportunities and challenges for the inner harbour of Port Adelaide, Australia. Australian Geographer 40: 297-317.

257. O'Connor K (1989) Australian ports, metropolitan areas and trade-related services. Australian Geographer 20: 167-172.

258. O'Connor K (2010) Global city regions and the location of logistics activity. Journal of Transport Geography 18: 354-362.

259. O'Dell AC (1951) Some geographical aspects of the location of ports as illustrated by the Atlantic seaboard of Europe. Tijdschrift voor Economische en Sociale Geografie 42: 373-378.

260. O'Dell AC (1951) The physical background to port development. Tijdschrift voor Economische en Sociale Geografie 42: 349-351.

261. Ogundana B (1972) Oscillating seaport location in Nigeria. Annals of the Association of American Geographers 62: 110-121.

262. Oliver J (1966) Port Sudan: they study of its growth and functions. Tijdschrift voor Economische en Sociale Geografie 57(2): 54-61.

263. Olivier D and Slack B (2006) Rethinking the port. Environment and Planning A 38: 1409-1427.

264. Omiunu FGI (1989) The port factor in the growth and decline of Warri and Sapele townships in the western Niger Delta Region of Nigeria. Applied Geography 9: 57-69.

265. Oosterhaven J, Eding GJ and Stelder D (2001) Clusters, linkages and interregional spillovers: methodology and policy implications for the two Dutch mainports and the rural North. Regional Studies 35: 809-822.

266. Osleeb JP and Ratick SJ (1983) The impact of coal conversions on the ports of New England. Economic Geography 59: 35-51.

267. Ottens H (1972) A short review of postwar expansion schemes and present development with regard to the seaport of Amsterdam. Tijdschrift voor Economische en Sociale Geografie 63: 53-56.

268. Ouren T (1951) Transfer and transshipment, as exemplified by some Norwegian ports. Tijdschrift voor Economische en Sociale Geografie 42:378-381.

269. Overman HG and Winters LA (2005) The port geography of UK international trade. Environment and Planning A 37: 1751-1768.

270. Parola F and Veenstra AW (2008) The spatial coverage of shipping lines and container terminal operators. Journal of Transport Geography 16: 292-299.

271. Patton DJ (1956) The external port relations of Halifax and St. John. Annals of the Association of American Geographers 46: 269.

272. Patton DJ (1957) Some recent literature on ports. Annals of the Association of American Geographers 47: 193-195. 
273. Patton DJ (1957) Spatial patterns of some American Atlantic and Gulf port hinterlands. Annals of the Association of American Geographers 47: 171-175.

274. Patton DJ (1958) General cargo hinterlands of New York, Philadelphia, Baltimore, and New Orleans. Annals of the Association of American Geographers 48: 436-455.

275. Patton DJ (1961) Railroad rate structures, ocean trade routes and the hinterland relations of Halifax and Saint John. Tijdschrift voor Economische en Sociale Geografie 52(1): 2-13.

276. Pearson RN (1958) The changing status of Barranquilla among the Ports of Colombia. Annals of the Association of American Geographers 48: 281.

277. Potrykowski M and Taylor Z (1986) Shipping policy and seaport development in Poland. Geojournal 12: 281-288.

278. Pred A (1984) Structuration, biography formation, and knowledge: observations on port growth during the late mercantile period. Environment and Planning D 2: 251-275.

279. Proudfoot PR (1982) Development of Botany Bay as a second seaport for Sydney. Australian Geographer 15: 159-169.

280. Randall DP (1968) Wilmington, North Carolina: The historical development of a port city. Annals of the Association of American Geographers 58: 441-451.

281. Rees H (1955) Lloyd's List as a source for port study in schools. Geography 40: 249254.

282. Rees H (1956) The shipment of petroleum to and from the ports of the United Kingdom. Scottish Geographical Journal 72: 109-113.

283. Rhynsburger LR (1950) Ice-modeled harbors of Puget Sound ports. Annals of the Association of American Geographers 40: 136.

284. Ridolfi G (1996) Italian ports and the wind of change. Tijdschrift voor Economische en Sociale Geografie 87: 348-356.

285. Ridolfi G (1999) Containerization in the Mediterranean between global ocean routeways and feeder services. GeoJournal 48: 29-34.

286. Rimmer PJ (1966) The problem of comparing and classifying seaports. The Professional Geographer 18: 83-91.

287. Rimmer PJ (1967) Changes in the ranking of Australian seaports 1951-2/1962-2. Tijdschrift voor Economische en Sociale Geografie 58: 28-38.

288. Rimmer PJ (1967) The changing status of New Zealand seaports, 1853-1960. Annals of the Association of American Geographers 57: 88-100.

289. Rimmer PJ (1967) The search for spatial regularities in the development of Australian seaports, 1861-1961/2. Geografiska Annaler - Series B: Human Geography 49: 42-54.

290. Rimmer PJ (1967) Recent changes in the status of seaports in the New Zealand coastal trade. Economic Geography 43: 231-243.

291. Rimmer PJ (1967) Inferred hinterlands: the example of New Zealand seaports. Geography 52: 384-392.

292. Rimmer PJ (1998) Ocean liner shipping services: corporate restructuring and port selection/competition. Asia Pacific Viewpoint 39: 193-208.

293. Rimmer PJ (1999) The Asia-Pacific Rim's transport and telecommunications systems: spatial structure and corporate control since the mid-1980s. Geojournal 48: 43-65.

294. Rimmer PJ and Comtois C (2009) China's container-related dynamics, 1990-2005. GeoJournal 74: 35-50.

295. Robinson R (1970) The hinterland-foreland continuum: concept and methodology. The Professional Geographer 22: 307-310. 
296. Robinson R (1971) Changing shipping technology and the spatial adjustment of port functions. Tijdschrift voor Economische en Sociale Geografie 62: 157-170.

297. Robinson R (1976) Modelling the port as an operational system: a perspective for research. Economic Geography 52: 71-86.

298. Robinson R (1984) Industrial strategies and port development in developing countries: the Asian case. Tijdschrift voor Economische en Sociale Geografie 76: 133-143.

299. Robinson R and Chu D (1978) Containerization and the port of Hong Kong in the 1970s. Australian Geographer 14: 98-111.

300. Rodgers AL (1957) The role of the State in the industrial development of the port of Genoa, Italy. Papers in Regional Science 3: 290-300.

301. Rodgers AL (1958) The port of Genova: external and internal relations. Annals of the Association of American Geographers 48: 319-351.

302. Rodrigue JP (2004) Freight, gateways and mega-urban regions: the logistical integration of the BostWash Corridor. Tijdschrift voor Economische en Sociale Geografie 95: 147-161.

303. Rodrigue JP (2006) Challenging the derived transport-demand thesis: geographical issues in freight distribution. Environment and Planning A 38: 1449-1462.

304. Rodrigue JP, Debrie J, Frémont A and Gouvernal E (2010) Functions and actors of inland ports: European and American dynamics. Journal of Transport Geography 18: 495-590.

305. Rodrigue JP and Notteboom TE (2010) Comparative North American and European gateway logistics: the regionalism of freight distribution. Journal of Transport Geography 18: 497-507.

306. Roso V, Woxenius J and Lumsden K (2009) The dry port concept: connecting container seaports with the hinterland. Journal of Transport Geography 17: 338-345.

307. Roudié P (1985) Long-distance emigration from the port of Bordeaux 1865-1920. Journal of Historical Geography 11: 268-279.

308. Sant M (1990) Accommodating recreational demand: boating in Sydney Harbour, Australia. Geoforum 21: 97-109.

309. Seaborne AA and Larrain PN (1983) Changing patterns of trade through the port of Thunder Bay. Canadian Geographer 27: 285-291.

310. Seitz KH (1959) Milwaukee's "Outside, Inside, Outside" Harbour. Annals of the Association of American Geographers 19(2): 210.

311. Senior ML (1983) The British Ministry of Transport's study of the Portbury Dock proposal, 1966: a reappraisal of the spatial analysis. Environment and Planning $C$ 1: 85105.

312. Sharpless JB (1976) The economic structure of port cities in the mid-nineteenth century: Boston and Liverpool, 1840-1860. Journal of Historical Geography 2: 131-143.

313. Sinclair R (1957) Coal port hinterlands of Northern Ireland. Annals of the Association of American Geographers 47: 178.

314. Slack B (1980) Technology and seaports in the 1980s. Tijdschrift voor Economische en Sociale Geografie 71: 108-113.

315. Slack B (1988) The evolution of Montreal's port service industry. Canadian Geographer 32: 124-132.

316. Slack B (1989) The port service industry in an environment of change. Geoforum 20: 447-457. 
317. Slack B (1989) Port services, ports and the urban hierarchy. Tijdschrift voor Economische en Sociale Geografie 80: 236-243.

318. Slack B (1990) Intermodal transportation in North American and the development of inland load centres. The Professional Geographer 42: 72-83.

319. Slack B and Wang JJ (2002) The challenge of peripheral ports: an Asian perspective. GeoJournal 56: 159-166.

320. Solomon RJ (1963) External relations of the port of Hobart 1804-1961. Australian Geographer 9: 43-53.

321. Solomon RJ (1963) Four stages in port evolution - the case of Hobart. Tijdschrift voor Economische en Sociale Geografie 54: 159-168.

322. Sommers LM (1960) Distribution and significance of the foreign trade ports of Norway. Economic Geography 36: 306-312

323. Song DW (2002) Regional container port competition and co-operation: the case of Hong Kong and South China. Journal of Transport Geography 10: 99-110.

324. Soppé M, Parola F and Frémont A (2009) Emerging inter-industry partnerships between shipping lines and stevedores: from rivalry to cooperation? Journal of Transport Geography 17: 10-20.

325. Stanley WR (1970) Transport expansion in Liberia. Geographical Review 60: 529-531.

326. Stanley WR (1990) A third port for Southwest Africa/Namibia? GeoJournal 22: 363378.

327. Stevens BH, Treyz GI and Kindahl JK (1981) Conjoining an input-output model and a policy analysis model: a case study of the regional economic effects of expanding a port facility. Environment and Planning A 13: 1029-1038.

328. Stevenson D (1999) Reflection of a 'great port city': the case of Newcastle, Australia. Environment and Planning D 17: 105-119.

329. Stobart J (2004) Personal and commercial networks in an English port: Chester in the early eighteenth century. Journal of Historical Geography 30: 277-293.

330. Stojanovic TA, Smith HDO and Wooldridge CF (2006) The impact of the Habitats Directive on European port operations and management. Geojournal 65: 165-176.

331. Suggate LS (1963) Christchurch, New Zealand, and its port. Geography 48: 326-328.

332. Sun NC and Bunamo MC (1973) Competition for handling U.S. foreign trade cargoes: the port of New York's experience. Economic Geography 49: 156-162.

333. Suykens F (1989) The city and its port - an economic appraisal. Geoforum 20: 437-445.

334. Sweet DC (1969) Hinterland analysis and port trade potential. Annals of the Association of American Geographers 59: 204.

335. Svendsen AS (1952) A note on port statistics. Tijdschrift voor Economische en Sociale Geografie 42: 354-360.

336. Tan TY (2007) Port cities and hinterlands: a comparative study of Singapore and Calcutta. Political Geography 26: 851-865.

337. Tavasszy L, Minderhoud M, Perrin JF and Notteboom TE (2011) A strategic network choice model for global container flows: specification, estimation and application. Journal of Transport Geography 19: 1163-1172.

338. Tavener LE (1950) The port of Southampton. Economic Geography 26: 260-273.

339. Taylor MJ (1974) The impact of New Zealand's secondary ports in their associated urban communities. New Zealand Geographer 30: 35-53.

340. Thill JC and Lim HW (2010) Intermodal containerized shipping in foreign trade and regional accessibility advantages. Journal of Transport Geography 18: 530-547. 
341. Thoman RS (1956) A foreign-trade zone (free port) on the Great Lakes- St. Lawrence seaway. Annals of the Association of Americans Geographers 46: 271-275.

342. Thomas BE (1957) Railways and ports in French West Africa. Economic Geography 33: $1-15$.

343. Thomas GH (1969) The new iron ore terminal at Port Talbot. Geography 54: 336-338.

344. Thompson K (1958) Sacramento as an inland port. Annals of the Association of American Geographers 48: 292-293.

345. Todd D (1993) The interplay of trade, regional and technical factors in the evolution of a port system: the case of Taiwan. Geografiska Annaler - Series B: Human Geography 75: 3-18.

346. Todd D (1994) Changing technology, economic growth and port development: the transformation of Tianjin. Geoforum 25: 285-303.

347. Todd D (1996) North-South energy resource transfers in China and the port intermediary. Tijdschrift voor Economische en Sociale Geografie 87: 195-208.

348. Todd D (1997) China's energy needs, coal transfers and the ports sector. Geoforum 28: 39-53.

349. Todd D and Hsueh YC (1990) New port developments and balanced regional growth: a Taiwan example. Geoforum 21: 421-433.

350. Todd D and Zhang L (1993) Political and technical factors impinging on port operations: the case of Manchuria. GeoJournal 30: 441-454.

351. Toschi U (1951) Studi geografici sui porti industriali italiani. Tijdschrift voor Economische en Sociale Geografie 42: 381-382.

352. Tregear TR (1954) Shih Hui Yao. A Chinese river port with a future. Geography 39: 113-117.

353. Tuppen JN (1975) Fos, Europort of the South. Geography 60: 213-217.

354. Ubogu AE, Ariyo JA and Mamman M (2011) Port-hinterland trucking constraints in Nigeria. Journal of Transport Geography 19: 106-114.

355. Udo RK and Ogundana B (1966) Factors influencing the fortunes of ports in the Niger delta. Scottish Geographical Journal 82: 169-183.

356. Uernstedt FL (1966) Cebu: focus of Philippine inter-island trade. Economic Geography.

357. Vallega A (1986) Maritime impacts on the littoral organization - the case of the Western Mediterranean. Geojournal 12: 271-279.

358. Van Dongen IS (1961) Coffee trade, coffee regions, and coffee ports in Angola. Economic Geography 37: 320-346.

359. Van Hasselt PJ (1959) Delfzijl Port Authority. Tijdschrift voor Economische en Sociale Geografie 50: 79-80.

360. Van Klink AH (1994) Strategic partnering among logistic nodes: Rotterdam and Eastern Europe. Journal of Transport Geography 2: 169-177.

361. Van Klink AH (1998) The port network as a new stage in port development: the case of Rotterdam. Environment and Planning A 30: 143-160.

362. Van Klink AH and Van den Berg GC (1998) Gateways and intermodalism. Journal of Transport Geography 6: 1-9.

363. Van Suylichem APGM (1968) Calcutta's new harbour as a magnet in the urbanisation process in Eastern India. Tijdschrift voor Economische en Sociale Geografie 59: 326334.

364. Veenstra A, Mulder HM and Sels RA (2005) Analyzing container flows in the Caribbean. Journal of Transport Geography 13: 295-305. 
365. Veenstra A and Notteboom TE (2011) The development of the Yangtze River container port system. Journal of Transport Geography 19: 772-781.

366. Vigarié A (1999) From break-bulk to containers: the transformation of general cargo handling and trade. Geojournal 48: 3-7.

367. Virarie A (1959) L'ensemble portuaire de la Baisse-Seine. Tijdschrift voor Economische en Sociale Geografie 50(6-7): 136-151.

368. Von Schirach-Szmigiel C (1973) Trading areas of the United Kingdom ports. Geografiska Annaler - Series B: Human Geography 55: 71-82.

369. Von Schirach-Szmigiel C (1978) Competition for the general cargo transports of Sweden's foreign trade. Geojournal 2: 133-146.

370. Waitt G and Hartig K (1997) Grandiose plans, but insignificant outcomes: the development of colonial ports at Twofold Bay, New South Wales. Australian Geographer 28: 201-218.

371. Walker AR (1989) Recessional and Gulf War impacts on port development and shipping in the Gulf States in the 1980's. GeoJournal 18: 273-284.

372. Wallace GJ (1975) Felixstowe: Britain's little big port. Geography 60: 209-213.

373. Wallace I (1975) Containerization at Canadian ports. Annals of the Association of American Geographers 65: 433-448.

374. Wang C and Ducruet C (2012) New port development and global city making: emergence of the Shanghai-Yangshan multiayered gateway hub. Journal of Transport Geography 25: 58-69.

375. Wang JJ (1998) A container load center with a developing hinterland: a case study of Hong Kong. Journal of Transport Geography 6: 187-201.

376. Wang JJ and Cheng MC (2010) From a hub port city to a global supply chain management center: a case study of Hong Kong. Journal of Transport Geography 18: 104-115.

377. Wang JJ and Ng AKY (2011) The geographical connectedness of Chinese seaports with foreland markets: a new trend? Tijdschrift voor Economische en Sociale Geografie 102: 188-204.

378. Wang JJ and Olivier D (2006) Port-FEZ bundles as spaces of global articulation: the case of Tianjin, China. Environment and Planning A 38: 1487-1503.

379. Wang JJ and Slack B (2000) The evolution of a regional container port system: the Pearl River Delta. Journal of Transport Geography 8: 263-275.

380. Ward M (1961) Malayan fishing ports and their inland connections. Tijdschrift voor Economische en Sociale Geografie 55: 113-142.

381. Ward M (1966) Major port hinterlands in Malaya. Tijdschrift voor Economische en Sociale Geografie 57: 242-251.

382. Warf B (1988) The Port Authority of New York-New Jersey. The Professional Geographer 40: 288-297.

383. Weigend GG (1952) Ports: their hinterlands and 'forelands'. Geographical Review 42: 660-662.

384. Weigend GG (1954) River ports and outports: Matadi and Banana. Geographical Review 44: 430-432.

385. Weigend GG (1955) Bordeaux: an example of changing port functions. Geographical Review 45: 217-243.

386. Weigend GG (1956) The functional development of the port of Hamburg. Tijdschrift voor Economische en Sociale Geografie 47: 113-120. 
387. Weigend GG (1956) The problem of hinterland and foreland as illustrated by the port of Hamburg. Annals of the Association of American Geographers 32: 1-16.

388. Weigend GG (1958) Some elements in the study of port geography. Geographical Review 48: 185-200.

389. Weigend GG (1961) Austria’s Ports. Geographical Review 51: 131-132.

390. Weigend GG (1973) Stages in the development of the ports of Rotterdam and Antwerp. Geoforum 4: 5-15.

391. West N (1989) Urban-waterfront developments: a geographic problem in search of a model. Geoforum 20: 459-468.

392. Wever E (1966) Pernis-Botlek-Europoort: un complexe a base de petrole. Tijdschrift voor Economische en Sociale Geografie 57: 131-140.

393. Wever E (1974) Seaports and physical planning in the Netherlands. Tijdschrift voor Economische en Sociale Geografie 65: 4-12.

394. White HP (1955) Port developments in the Gold Coast. Scottish Geographical Journal 71: 170-173.

395. White HP (1961) New ports in Dahomey and Togo. Geography 6(2): 160-163.

396. Wiegmans BW and Louw E (2011) Changing port-city relations at Amsterdam: a new phase at the interface? Journal of Transport Geography 19: 575-583.

397. Wiese B (1981) New ports as nodes for industrial and urban development: the case of Richards Bay and Saldanha Bay in South Africa. GeoJournal 2: 51-58.

398. Woxenius J and Bergqvist R (2011) Comparing maritime containers and semi-trailers in the context of hinterland transport by rail. Journal of Transport Geography 19: 680-688.

399. Wu J (2011) Between the centre and the periphery: the development of port trade in Darwin, Australia. Australian Geographer 42: 273-288. 


\section{Appendix II The list of major journals which have published extended port geography}

papers, 1950-2012

\begin{tabular}{|l|r|r|}
\hline \multicolumn{1}{|c|}{ Journal Name } & $\begin{array}{c}\text { No. of papers } \\
\text { published }\end{array}$ & $\%$ \\
\hline Maritime Policy \& Management & 85 & 25.8 \\
\hline Maritime Economics \& Logistics & 33 & 10.0 \\
\hline Cities & 9 & 2.7 \\
\hline International Journal of Transport Economics & 9 & 2.7 \\
\hline Ocean \& Coastal Management & 9 & 2.7 \\
\hline Transport Policy & 8 & 2.4 \\
\hline Transport Reviews & 8 & 2.4 \\
\hline African Urban Quarterly & 5 & 1.5 \\
\hline Growth \& Change & 5 & 1.5 \\
\hline Journal of International Logistics \& Trade & 5 & 1.5 \\
\hline Journal of Transport Economics \& Policy & 5 & 1.5 \\
\hline Transportation Research Part A & 5 & 1.5 \\
\hline Urban Studies & 5 & 1.5 \\
\hline European Journal of Transport \& Infrastructure Research & 4 & 1.2 \\
\hline Handbook of Terminal Planning & 3 & 0.9 \\
\hline Journal of the Eastern Asia Society for Transportation Studies & 3 & 0.9 \\
\hline Journal of Transport History & 3 & 0.9 \\
\hline The Dock \& Harbour Authority & 3 & 0.9 \\
\hline Town Planning Review & 3 & 0.9 \\
\hline Urban History Review & 3 & 0.9 \\
\hline & 3 & 64.7 \\
\hline Top 20 journals subtotal & 35.3 \\
\hline & 3 & 100.0 \\
\hline
\end{tabular}




\section{Appendix III 30 Top Positioned Papers in the Graph Combining Core Port Geography's Inward and Outward Citations, 1950-2012}

III.1 Including citations among core port geography papers

\begin{tabular}{|c|c|c|c|c|}
\hline Author(s) & Year & Journal & $\begin{array}{l}\text { Betweenness } \\
\text { centrality }\end{array}$ & In-degree $(\mathbf{k})$ \\
\hline Olivier \& Slack & 2006 & Environment \& Planning A & 861627 & 33 \\
\hline Lee, Song \& Ducruet & 2008 & Geoforum & 617629 & 23 \\
\hline $\mathrm{Ng} \&$ Pallis & 2010 & Environment \& Planning A & 617553 & 4 \\
\hline Norcliffe, Bassett \& Hoare & 1996 & Journal of Transport Geography & 424859 & 16 \\
\hline Herod & 1997 & Political Geography & 402831 & 70 \\
\hline Hayuth & 1981 & Economic Geography & 398309 & 70 \\
\hline Fowler & 2006 & Environment \& Planning A & 383426 & 2 \\
\hline Castree & 2000 & Economic Geography & 372852 & 47 \\
\hline Brenner & 1998 & Environment \& Planning D & 346815 & 3 \\
\hline Fleming \& Hayuth & 1994 & Journal of Transport Geography & 343972 & 70 \\
\hline Hoyle \& Charlier & 1995 & Journal of Transport Geography & 342499 & 17 \\
\hline Ducruet \& Notteboom & 2012 & Global Networks & 315295 & 0 \\
\hline Jacobs \& Notteboom & 2011 & Environment \& Planning A & 314736 & 1 \\
\hline Sager & 2011 & Progress in Planning & 306630 & 0 \\
\hline Weigend & 1958 & Geographical Review & 286304 & 48 \\
\hline Lee \& Ducruet & 2009 & Urban Geography & 272755 & 5 \\
\hline Van Klink & 1998 & Environment \& Planning A & 267569 & 2 \\
\hline Ducruet, Koster \& Van der Beek & 2010 & Regional Studies & 259654 & 1 \\
\hline Notteboom & 1997 & Journal of Transport Geography & 249122 & 40 \\
\hline Hoyle & 2000 & Geographical Review & 241449 & 16 \\
\hline Butler & 2007 & $\begin{array}{c}\text { International Journal of Urban \& } \\
\text { Regional Research }\end{array}$ & 233877 & 14 \\
\hline Van Klink \& Van den Berg & 1998 & Journal of Transport Geography & 233869 & 53 \\
\hline Jaffee & 2010 & Growth \& Change & 229725 & 0 \\
\hline Hoare & 1986 & Geografiska Annaler B & 225630 & 22 \\
\hline Airriess & 2001 & Geoforum & 221322 & 9 \\
\hline Turnbull & 2006 & $\begin{array}{c}\text { British Journal of Industrial } \\
\text { Relations }\end{array}$ & 218349 & 1 \\
\hline Notteboom \& Rodrigue & 2005 & Maritime Policy \& Management & 197708 & 27 \\
\hline Taaffe, Morrill \& Gould & 1963 & Geographical Review & 196444 & 32 \\
\hline Rimmer & 1967 & Geografiska Annaler B & 190960 & 24 \\
\hline Notteboom & 2010 & Journal of Transport Geography & 188358 & 4 \\
\hline
\end{tabular}


III.2 Excluding citations among core port geography papers

\begin{tabular}{|c|c|c|c|c|}
\hline Author(s) & Year & Journal & $\begin{array}{c}\text { Betweenness } \\
\text { centrality }\end{array}$ & In-degree $(\mathbf{k})$ \\
\hline Taaffe, Morrill \& Gould & 1963 & Geographical Review & 692061 & 32 \\
\hline Olivier \& Slack & 2006 & Environment \& Planning A & 625649 & 19 \\
\hline Notteboom \& Rodrigue & 2005 & Maritime Policy \& Management & 552420 & 27 \\
\hline $\mathrm{Ng} \&$ Pallis & 2010 & Environment \& Planning A & 532574 & 2 \\
\hline Jacobs \& Notteboom & 2011 & Environment \& Planning A & 421724 & 1 \\
\hline Herod & 1997 & Political Geography & 377897 & 69 \\
\hline Fowler & 2006 & Environment \& Planning A & 368060 & 2 \\
\hline Sager & 2011 & Progress in Planning & 335285 & 0 \\
\hline Lee, Song \& Ducruet & 2008 & Geoforum & 330285 & 13 \\
\hline Hayuth & 1981 & Economic Geography & 305765 & 34 \\
\hline Turnbull & 2006 & British Journal of Industrial Relations & 282187 & 1 \\
\hline Castree & 2000 & Economic Geography & 281055 & 46 \\
\hline Hoyle \& Charlier & 1995 & Journal of Transport Geography & 280673 & 11 \\
\hline Van Klink \& Van den Berg & 1998 & Journal of Transport Geography & 269459 & 41 \\
\hline Butler & 2007 & $\begin{array}{c}\text { International Journal of Urban \& } \\
\text { Regional Research }\end{array}$ & 256594 & 14 \\
\hline Van Klink & 1998 & Environment \& Planning A & 252516 & 1 \\
\hline Fleming \& Hayuth & 1994 & Journal of Transport Geography & 251471 & 50 \\
\hline Norcliffe, Bassett \& Hoare & 1996 & Journal of Transport Geography & 228482 & 9 \\
\hline Airriess & 2001 & Geoforum & 227528 & 6 \\
\hline Brenner & 1998 & Environment \& Planning D & 222676 & 3 \\
\hline Notteboom \& Winkelmans & 2001 & Maritime Policy \& Management & 213766 & 11 \\
\hline Hoyle & 2000 & Journal of Maritime Research & 189210 & 0 \\
\hline Jaffee & 2010 & Growh \& Change & 187488 & 0 \\
\hline Robinson & 2002 & Maritime Policy \& Management & 184823 & 20 \\
\hline Desfor & 2004 & European Planning Studies & 182581 & 15 \\
\hline Wang \& Ducruet & 2012 & Journal of Transport Geography & 172690 & 0 \\
\hline Lee \& Ducruet & 2009 & Urban Geography & 172293 & 4 \\
\hline Dias, Calado \& Mendoça & 2010 & Journal of Transport Geography & 167667 & 4 \\
\hline Ducruet, Ietri \& Rozenblat & 2011 & Cybergeo & 166501 & 0 \\
\hline Notteboom & 2010 & Journal of Transport Geography & 164827 & 2 \\
\hline
\end{tabular}

